\title{
Application of Carbon lon and Its Sensitizing Agent in Cancer Therapy: A Systematic Review
}

\author{
Xiaolin Wang, Xiaojun Chen, Guangfei Li, Xiao Han, Tianxin Gao, Weifeng Liu \\ and Xiaoying Tang *
}

School of Life Science, Institute of Engineering Medicine, Beijing Institute of Technology, Beijing, China

OPEN ACCESS

Edited by:

Alan Jay Katz,

St. Francis Hospital,

United States

Reviewed by:

Anielle Almeida,

Federal University of Alagoas, Brazil

Junwei Shi,

University of Miami, United States

*Correspondence:

Xiaoying Tang

xiaoying@bit.edu.cn

Specialty section:

This article was submitted to

Radiation Oncology,

a section of the journal

Frontiers in Oncology

Received: 12 May 2021

Accepted: 21 June 2021

Published: 05 July 2021

Citation:

Wang $X$, Chen $X, L i G$,

Han X, Gao T, Liu W

and Tang X (2021) Application

of Carbon Ion and Its Sensitizing

Agent in Cancer Therapy:

A Systematic Review.

Front. Oncol. 11:708724.

doi: 10.3389/fonc.2021.708724
Carbon ion radiation therapy (CIRT) is the most advanced radiation therapy $(\mathrm{RT})$ available and offers new opportunities to improve cancer treatment and research. CIRT has a unique physical and biological advantage that allow them to kill tumor cells more accurately and intensively. So far, CIRT has been used in almost all types of malignant tumors, and showed good feasibility, safety and acceptable toxicity, indicating that CIRT has a wide range of development and application prospects. In addition, in order to improve the biological effect of CIRT, scientists are also trying to investigate related sensitizing agents to enhance the killing ability of tumor cells, which has attracted extensive attention. In this review, we tried to systematically review the rationale, advantages and problems, the clinical applications and the sensitizing agents of the CIRT. At the same time, the prospects of the CIRT in were prospected. We hope that this review will help researchers interested in CIRT, sensitizing agents, and radiotherapy to understand their magic more systematically and faster, and provide data reference and support for bioanalysis, clinical medicine, radiotherapy, heavy ion therapy, and nanoparticle diagnostics.

Keywords: heavy ion radiotherapy, carbon therapy, radiation therapy, clinical application, sensitizing agent

\footnotetext{
Abbreviations: CIRT, Carbon Ion Radiation Therapy; RT, Radiation Therapy; NCDs, Noncommunicable Diseases; WHO, World Health Organization; LBNL, Lawrence Berkeley National Laboratory; HIMAC, Heavy Ion Medical Accelerator; NIRS, National Institute of Radiological Science; HIRFL, Lanzhou Heavy Ion Research Facility; HIT, Heidelberg Ion-beam Therapy Center; PTCOG, Proton Therapy Co-Operative Group; SOBP, Spread-out Bragg peak; PET, Positron Emission Tomography; LET, Linear Energy Transfer; RBE, Relative Biological Effects; SSBs, Single Strand Breaks; DSBs, Double Strand Breaks; ROS, Reactive Oxygen Species; OER, Oxygen Enhancement Ratio; CNS, Central Nervous System; PTV, Planning Target Volume; CTV, Clinical Target Volume; GdNPs, Gadolinium-based Nanoparticles; GONs, Gadolinium Oxide Nanocrystals; GNP, Gold Nanoparticles; GBNPs, Gadolinium Based Nanoparticles; UMIN, University Hospital Medical Information Network; NPC, Nasopharyngeal Carcinoma; STS, Osteosarcomas and Soft Tissue Sarcomas; HCC, Hepatocellular Carcinomas; LACC, Locally Advanced Cervical Cancer; LRFS, Local Relapse Free Survival; RRFS, Regional Relapse Free Survival.
} 


\section{INTRODUCTION}

Currently, noncommunicable diseases (NCDs) are the leading cause of death globally, and cancer is expected to become the leading cause of death worldwide in the 21st century and the single most important barrier to improving life expectancy (1-3). Cancer has a high incidence and mortality rate worldwide, which is the first or second leading cause of death globally. According to the latest report data of World Health Organization (WHO), worldwide, an estimated 19.3 million new cancer cases occurred in 2020, of which $49.3 \%$ in Asia and 22.8\% in Europe; almost 10.0 million cancer deaths occurred, with $58.3 \%$ in Asia and $19.6 \%$ in Europe. The most common cancers were breast, lung, prostate and colon cancer, with breast cancer having the highest incidence at about $11.7 \%$. In addition, the cancers with high mortality mainly included lung cancer, liver cancer, stomach cancer and breast cancer, among which the death rate of lung cancer was the highest, up to $18.0 \%$, followed by liver cancer, which was about $8.3 \%$ (4).

Radiation therapy (RT) is one of the oldest forms of cancer treatment, with more than $50 \%$ of cancer patients receiving additional RT at various stages, and more than $70 \%$ using RT in developed countries (5). More than two-thirds of cancer patients receive RT alone or in combination with other cancer treatments, such as surgery or chemotherapy, especially those with local or regional advanced stage (6). With the rapid development of science and technology, radiotherapy technology has been developing constantly. The common RT mainly includes X-ray radiotherapy (XRT), $\gamma$-ray radiotherapy $(\gamma \mathrm{RT})$, electron radiotherapy, proton therapy $(\mathrm{PT})$ and heavy ion radiation therapy (the most common heavy ion therapy is carbon ion therapy, CIRT). X-rays are made up of photons and can pass directly through the body, but they may have serious side effects when they pass through healthy tissue. Compared to X-rays, $\gamma$ rays have shorter wavelengths and are more penetrating, and gamma knife currently refers to $\gamma$-rays. However, the action of $\gamma$ rays is usually relatively slow and the damage to normal tissue is significant. Protons are positively charged particles that stop moving when they hit a target, reducing the chance of causing damage to healthy tissue. Among the new technologies in RT, the use of carbon ions marks a new era in the field of high-precision cancer treatment. Carbon ions have a larger mass, which reduces the transverse scattering of carbon ions and improves the radiation accuracy. On top of that, the dose of carbon ions drops faster than the dose of protons, which keeps the normal tissue around the tumor in better shape. The unique physical and biological characteristics of CIRT give it significant advantages over other RT (7). So far, CIRT has been used in almost all types of malignant tumors and has been extensively studied in recurrent diseases.

Here we summarize CIRT unique physical and biological characteristics and advantages, and lists the clinical trials and research by CIRT in recent years, and summarized the related clinical data, including the number of cases, carbon ion dose, local control rate, over survival rate and the toxicity. Finally, the related radiation sensitizers of carbon ion were preliminarily explored. We believe that CIRT is very promising and has the potential to be the most attractive cancer treatment option.

\section{THE HISTORY AND CHARACTERISTICS FOR CIRT}

\section{History}

In 1946, Robert Rathbun Wilson was the first to propose the use of heavily charged particles and fast protons for the treatment of cancer. In 1954, Lawrence Berkeley National Laboratory (LBNL) first used protons for therapeutic studies, and helium ions were studied three years later. In 1975, LBNL started a clinical trial study of heavy ion cancer treatment using a high-energy heavy ion synchronous cyclotron. It was found that the local control rate of heavy ion radiotherapy was 2-3 times higher than that of conventional radiation such as X-rays, gamma rays and electron beams. In 1990, the American Fermi Laboratory used a rotating gantry (which can rotate the number of protons) to build the first proton beam radiotherapy equipment. This equipment can emit proton beams from different directions through the isocentric gantry, thereby reducing skin and damage to normal cells between tumors, increasing the scorch-to-skin ratio during treatment. In 1993, the Japanese government built the world's first heavy ion medical accelerator (HIMAC) at the National Institute of Radiological Science (NIRS) in Chiba Prefecture, which is specially used for CIRT and radio medical research (8). More than twenty thousand patients were subsequently treated with CIRT (9). HIMAC treatment device mainly includes synchrotron, beam distribution and irradiation system, patient positioning system and treatment plan system. Its ion beam type is ${ }^{4} \mathrm{He} \sim \mathrm{Ar}$, beam intensity is $10^{7} \sim 10^{10} \mathrm{pps}$, and the maximum energy can reach $800 \mathrm{MeV} / \mathrm{u}$ dose rate, and control at about 5 Gy/min. The patients treated included head and neck tumors, brain tumors, lung cancer, liver cancer, prostate cancer, and cervical cancer. For head and neck tumors, a local tumor control rate of more than $80 \%$ has been achieved; for overall treatment, good curative effects have been achieved without obvious complications, and the tumor growth inhibition rate is high. Encouraged by the results of this HIMAC treatment, Japan built another medical HIMAC in Hyogo in 1996. The synchrotron can provide $230 \mathrm{MeV}$ proton beam, $230 \mathrm{MeV} / \mathrm{u}$ helium ion beam and $320 \mathrm{MeV} / \mathrm{u}$ carbon ion beam. The treatment device was completed in 2000 and began to receive patient treatment in 2001. In 1997, the Heavy Ion Research Center in Darmstadt, Germany, used the treatment characteristics and experience of the ${ }^{20} \mathrm{Ne}$ ion beam of the American LBNL and the ${ }^{12} \mathrm{C}$ ion beam of the Japanese NIRS to develop and apply advanced raster magnetic scanning system and positron emission tomography. The two major technical methods of surgery have achieved heavy ion beam conformal radiotherapy and real-time online monitoring of beam current. In December of the same year, two cases of skull base tumors were treated with heavy ion beams. A clinical follow-up study three months after treatment showed that hypocranial tumors basically disappeared. In 2005, 
the Institute of Modern Physics (IMP) of the Chinese Academy of Sciences built a superficial tumor heavy ion therapy terminal based on the Lanzhou Heavy Ion Research Facility (HIRFL), and used the $80 \mathrm{MeV} / \mathrm{u}$ carbon ion beam provided by HIRFL in the following year. The Multi-Layer Cancer Terminal conducted the first clinical treatment trial on 4 patients with melaleuca malignant cases, which also made China the fourth country in the world to conduct heavy ion clinical trials. In 2007, IMP used $100 \mathrm{MeV} / \mathrm{u}$ carbon ion beam provided by HIRFL to treat 23 patients with tumors. After a course of carbon ion radiotherapy in the 27 patients before and after, most of the tumors of the patients have completely disappeared, and the rest of the patients have reduced to varying degrees. The patients did not have any local or systemic adverse reactions. At the end of 2008, IMP built a deep tumor heavy ion therapy terminal based on the Lanzhou HIMAC cooling storage ring. By the end of 2014, a total of 18 batches of 213 tumor patients (103 cases of superficial and 110 cases of deep) were treated before and after IMP, and significant effects were achieved. In 2009, Germany established the Heidelberg ion-beam therapy center (HIT) and officially opened it in 2012. HIT mainly treats brain tumors, thyroid tumors, lung (far away from the heart) tumors, liver tumors, and prostate tumors. In March 2015, after review and approval by the China National Food and Drug Administration (CFDA), the proton carbon ion treatment equipment of the Shanghai Proton Heavy Ion Hospital was approved for the first time in China and officially operated in May of the same year. The main types of diseases currently treated are: nasopharyngeal carcinoma, chordoma, chondrosarcoma, early and locally advanced lung cancer, part of thymic cancer and chest metastatic tumors, liver cancer, pancreatic cancer, prostate cancer, etc. Regardless of whether these cancer patients received treatment during the treatment phase or the discharge follow-up phase, the tumor condition control was good, the patient's disease indications also stabilized, and the overall condition was good. For the entire timeline of events, kindly refer to Figure 1.

According to the data published by the Proton Therapy CoOperative Group (PTCOG, https://www.ptcog.ch/, last update: Feb 2021), there are nearly 175 particle therapy centers in operation, construction or planning worldwide, including 12 CIRT centers in operation. The distribution of the world protons and CIRT center in countries of the world and the number of patients who have received particle therapy have been presented in Figure 2. In addition, according to the "Patient Statistics" published by PTCOG, we know that about 220,000 patients are treated with particle therapy, and about $14 \%$ of them are treated with CIRT. The rapid development of heavy ion radiotherapy is in Japan and Germany. Japan is also the country with the most clinical trials of CIRT (10). Currently, six carbon ion treatment centers are under construction and two are planned. Table 1 details the number of CIRT centers worldwide, the highest energy, the type of accelerator, the start time of treatment or the planned treatment time. As can be seen from Table 1, the use of CIRT is not yet widespread and is still considered "experimental" for many tumor sites, but clinical indication guidelines are being developed (11).

\section{Rationale}

\section{Physics Rationale}

In the process of penetrating tissues, charged particles can produce a characteristic depth dose curve. The radiation dose is released rapidly at the end of the particle's range and reaches the peak, forming the Bragg peak. CIRT often takes advantage of this characteristic to insert Bragg peak into tumor tissue. But because Bragg Peak is usually not wide enough to cover most tumor tissues. The penetration depth is a function of initial kinetic energy and particle charge. A higher energy particle can penetrate deeper, while a larger charged particle with the same

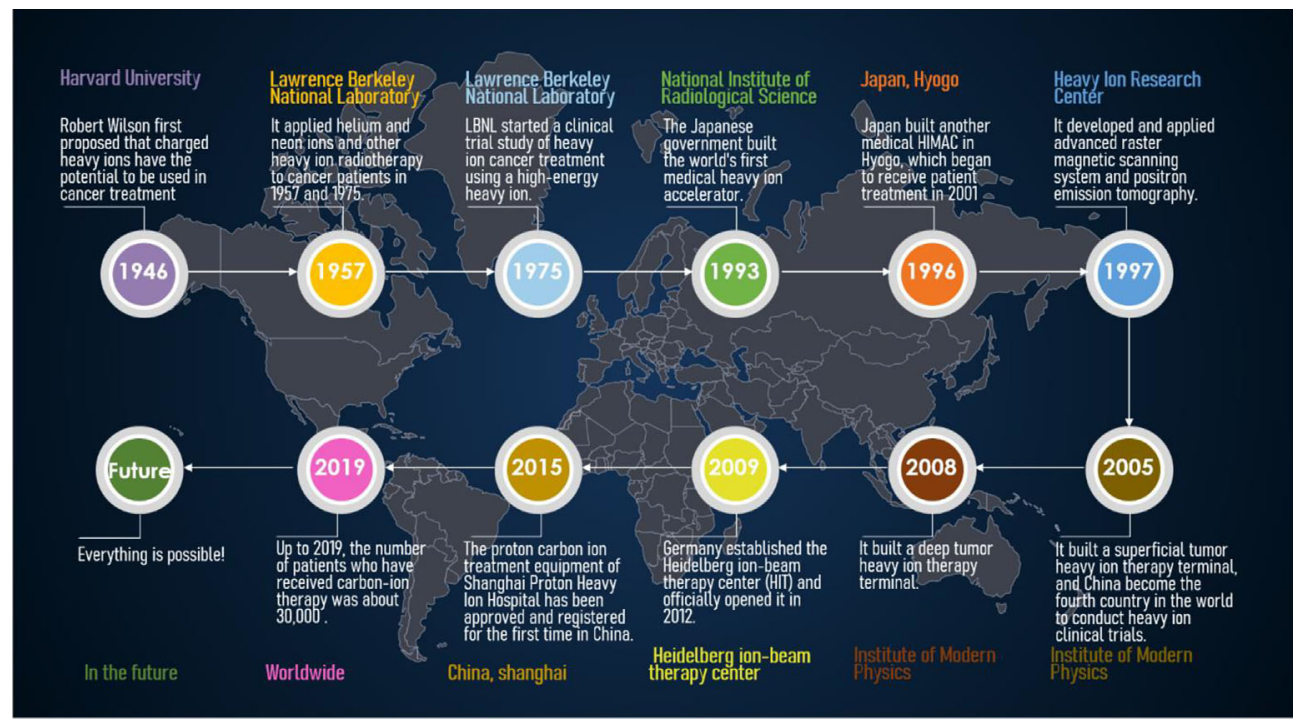

FIGURE 1 | Timeline of major events in heavy ion therapy. 


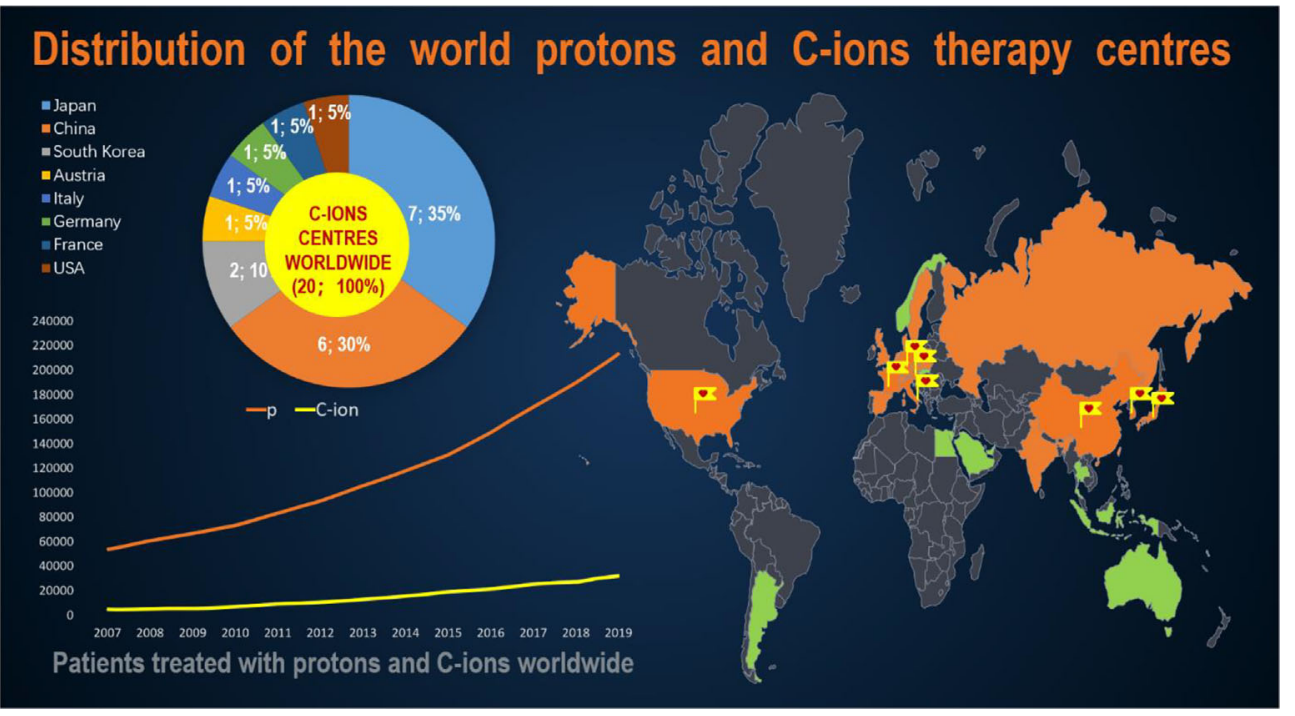

FIGURE 2 | Distribution of the world protons and C-ions therapy centers.

initial kinetic energy can penetrate shallower. So using particles with different initial kinetic energy properly weighted, each other can in depth (or bundle) directions to create a uniform dose (or is, in fact, any shape the physical dose distribution) of areas to cover need treatment of lesions, produce a spread-out Bragg peak (SOBP), covering the entire tumor tissue, thus providing the required radiation dose to the target tissue. This dose deposition pattern is the basis of charged particle therapy for malignancy, enhancing dose distribution and transverse focusing. SOBP enables particle therapy to have a good dosimetric distribution, which maximizes the killing of tumor tissues and protects the normal tissues around the tumor to the greatest extent.
This physics rationale of SOBP offer several significant benefits for particle therapy compared to other RT (12): First, the proportion of the dose deposited into the tumor is increased relative to the dose deposited in healthy tissue close to the tumor. Second, less dose is given to normal tissue at the back end of Bragg Peak, which allows more retention of normal tissue at the distal edge of the tumor (13). Third, they can be magnetically guided rather than physically aligned, which allows clinicians to map a three-dimensional tumor with radiation doses while minimizing radiation to nearby dangerous structures. Compared with PT, CIRT shows inhibited multiple coulomb scattering during the movement of carbon ions, which results in

TABLE 1 | Distribution of the world C-ions therapy center in operation, under construction and in planning stage.

\begin{tabular}{|c|c|c|c|c|}
\hline Operating conditions & Country & Who, Where & MAX. Energy (MeV) & Start of treatment \\
\hline \multirow[t]{12}{*}{ Facilities in Operation } & Austria & MedAustron, Wiener Neustadt & S 403/u & 2019 \\
\hline & China & SPHIC, Shanghai & S 430/u & 2014 \\
\hline & China & Heavy Ion Cancer Treatment Center, Wuwei, Gansu & S $400 / u$ & 2019 \\
\hline & Germany & HIT, Heidelberg & S $430 / u$ & 2009, 2012 \\
\hline & Germany & MIT, Marburg & S $430 / u$ & 2015 \\
\hline & Italy & CNAO, Pavia & S 480/u & 2012 \\
\hline & Japan & HIMAC, Chiba & S 800/u & 1994, 2017 \\
\hline & Japan & HIBMC, Hyogo & S 320/u & 2002 \\
\hline & Japan & GHMC, Gunma & S 400/u & 2010 \\
\hline & Japan & SAGA-HIMAT, Tosu & S $400 / 4$ & 2013 \\
\hline & Japan & i-Rock Kanagawa Cancer Center, Yokohama & S $430 / u$ & 2015 \\
\hline & Japan & Osaka Heavy Ion Therapy Center, Osaka & S $430 / u$ & 2018 \\
\hline \multirow[t]{6}{*}{ Facilities under Construction } & China & HITFil at IMP, Lanzhou, Gansu & $400 / u$ & $2021 ?$ \\
\hline & France & ARCHADE, Caen & $400 / 4$ & 2023 \\
\hline & Japan & Yamagata University Hospital, Yamagata & $430 / 4$ & 2021 \\
\hline & South Korea & KIRAMS, Busan & $430 / 4$ & 2025 \\
\hline & South Korea & Yonsei University Hospital, Seoul & $430 / u$ & 2022 \\
\hline & China & Taipei Veterans General Hospital, Taipei & $430 / 4$ & $2021 / 2022$ \\
\hline \multirow[t]{2}{*}{ Facilities in Planning Stage } & China & Himed Cancer Hospital, Xuzhou City, Jiangsu Province & $430 / 4$ & $2022 ?$ \\
\hline & USA & Mayo Carbon Ion Therapy Center, Jacksonville, FL. & $250,430 / u$ & $2025+$ \\
\hline
\end{tabular}

S, Synchrotron; ? = open (last update: Feb 2021). 
a sharper side penumbra of the heavy ion beam. The clinical use of the fact that the carbon ion beam can potentially be placed laterally closer to the organ at risk while maintaining a high degree of organ preservation. On the other hand, because the relative bioavailability (RBE) of PT is only $10 \%$ higher than that of XRT (14), therapeutic resistance may still exist in the tumor microenvironment. Carbon ions, on the other hand, take advantage of their greater mass, which leads to more severe DNA damage, and the new effect of this damage can be increased by about $2-4$ times $(15,16)$.

The possibility of dose verification by available imaging. Dose verification is a key link in the process of CIRT, which can accurately evaluate the tumor target area and surrounding normal tissue of patients, improve the target dose and local control rate, and reduce the radiation dose of target area and surrounding normal tissue, so as to ensure the treatment quality of CIRT. As carbon ions move through a substance, nuclear interactions occur in both the ion projectile and the traversing substance. Some of these nuclei interact to produce positron emission nuclei, which can be imaged using positron emission tomography (PET) scanners.

Superior linear energy transfer. CIRT has a potential clinical advantage in that heavily charged particles with higher let values than photons or protons are used. It is widely believed that carbon ions are more effective in the treatment of radiationresistant cancers, such as recurrent nasopharyngeal cancer, prostate cancer, bone and soft tissue tumors, head and neck cancer and so on, because of their high linear energy transfer (LET), which can cause more direct double-stranded DNA damage (17). The LET of a particle can be determined by many factors, but the two most important factors are ion charge and ion velocity. Heavier charged particles can adjust their speed to meet high or low LET requirements. In the entrance area of tissues, their LET values are lower due to their high speed, and increase under lower kinetic energy as the particles stay in the deeper area of the tumor. Osama et al. (6) believed that the dose distribution of particles with high LET values on the nanometer and micron scales was the result of large ionization event clusters along particle tracks caused by direct or collision events (intensive ionization). This event indicates a sharp increase in trace doses, leading to the destruction of DNA and other related biomolecules, which is considered to be more complex, so it may lead to more serious relative biological effects (RBE) than low LET radiation, which means that the higher the LET value of the same absorbed dose, the greater the RBE (18).

\section{Biological Rationale}

The biological principles of CIRT mainly include high RBE, more complex DNA damage, higher oxygen enhancement ratio and more complex lethal mechanism. The researchers came up with the concept of RBE in order to compare the effects of different types of radiation. RBE is defined as the ratio of the test radiation dose to the reference radiation that produces the same biological endpoint. X-rays are generally considered to have an RBE of 1, independent of energy. The International Radiation Unit and Measurement Committee recommends that the RBE value of the proton is 1.1 (19). Compared with other rays, carbon ion rays have a higher $\mathrm{RBE}$. The RBE value of carbon ions that is clinically recognized is 1.1-4.0 depending on the cell line (11), but there are also reports in the literature that its $\mathrm{RBE}$ value reaches 5 . There are many factors that affect the $\mathrm{RBE}$ value, such as LET, ion type, dose per fraction, cell/tissue type of action, etc. Therefore, for $\mathrm{C}$ ions, $\mathrm{RBE}$ value is variable, so more experiments and data are needed to verify. Jeong studied and summarized the relative biological effects of CIRT on early lung cancer (10). In this work, they used a tumor mechanism response model for photonic radiotherapy of the lung to estimate the RBE of CIRT relative to photonic radiotherapy. Fractional dose, number of fractions, treatment schedule, and local control rates were used to simulate the model with respect to the standard photon results. The dose-response relationship of the obtained CIRT was compared with the previously determined dose-response relationship of photonic radiotherapy for lung cancer, and the $\mathrm{RBE}$ of the CIRT was derived. The results showed that with the increase of fractional dose, the number of fractional dose decreased, and the RBE value decreased, and the derived RBE ranged drops from 2.1 to 1.5. In this study, the clinical experience of photonic radiotherapy and CIRT in the treatment of early lung tumors was integrated, with few fitting parameters and clear mechanism significance.

Unlike low LET radiation, when using a high-LET CIRT, humans are exposed to a high energy charge depositing a large amount of energy along the through-path. DNA damage caused by high LET radiation is complex and varied, including single strand breaks (SSBs), chemically altered base damage, intra strand crosslinking, double strand breaks (DSBs) and "cluster" damage, etc. The complex DNA damage repair response caused by high LET radiation is less efficient, and what's more it is difficult to use a single DNA repair method to repair, which may eventually lead to genomic instability and cell death. The damage of complex DNA aggregation induced by high LET radiation (including carbon ions) is caused by multiple DNA damage, and the specific mechanism needs to be further studied. In fact, many reports have confirmed this complexity. The main reason for the increase in cancer mortality is the inability of DNA repair pathways to faithfully handle these repaired or mishandled complex lesions. In addition, since carbon ions with high LET induce complex DNA damage that is difficult to repair, CIRT is considered to be effective in killing chemoradio-resistant tumors.

In addition to the direct damage to DNA caused by carbon ion radiation, carbon ion radiation also affects the liquid in the cell. For example, in the process of radiation, the water in the cell will cause hydrolysis and lead to the accumulation of reactive oxygen species (ROS), and the accumulation of these reactive oxygen species will cause secondary damage to tumor cells, tissues, etc., that is, the so-called "indirect damage". One requirement for maximum ROS-related damage is the presence of molecular oxygen, which fixes or makes permanent the damage caused by ROS. Quantifying the effect of oxygen is done through the oxygen enhancement ratio (OER). Similar in concept to RBE, the OER seeks to assess the amount of dose necessary to result in an equivalent biological endpoint with or 
without the presence of oxygen. In contrast, the estimated OER for carbon and other heavy ions may decrease with the increase of LET, and the OER can drop from 2.5 to 1.0 depending upon the ion charge and LET (20). Therefore, high LET particles at the appropriate LET (depths) are more effective at killing cells in the hypoxic, necrotic cores of tumors compared to photons, lending particle therapy yet another biological advantage over photons. In addition, heavy ion scattering is relatively small, which is very beneficial to accurate dose distribution.

CIRT has little dependence on cell cycle and oxygen concentration, and can trigger cell death through a variety of mechanisms, including apoptosis, necrosis, autophagy, premature aging, accelerated differentiation and/or delayed germ cell death. CIRT induced DNA damage is a mitotic catastrophe. Some scholars have contrasted the treatment of cancer cells with $\mathrm{C}$ ions and cisplatin, X-rays, and the results showed that mitotic catastrophe was triggered by CIRT (21). The authors suggested that aberrant mitosis and subsequent mitotic catastrophe resulted from less efficient repair of the more complex DSBs after CIRT. It can be seen that compared with ordinary photons/rays, the gene expression induced by carbon ions has a greater difference. Among them, genes related to cell metabolism, cell/organelle tissue, cell cycle, DNA damage and repair pathway were up-regulated or down-regulated. These changes, in turn, make carbon ion damage to DNA more lethal and lower the rate of DNA repair. Of course, DNA DSBs are the deadliest among them. This damage makes it difficult for DNA to repair itself and eventually leads to cell death.

\section{Advantages}

Many cancer patients use X-rays, but when X-rays are delivered from an external source, they not only kill the target cancer cells, but they also damage healthy tissue by depositing most of their energy in it. X-ray is a kind of electromagnetic wave. The particle size of the carbon ion is significantly larger than that of the proton (Figure 3A).

Carbon ion irradiation has potential advantages over X-ray, including better physical dose distribution, greater reduction in lateral scattering (22), higher RBE and lower OER, all of which are ideal characteristics for killing radiation-resistant hypoxic tumors. The biggest difference between high-energy carbon ion beams and conventional X-rays is the depth dose curve, as shown in Figure 3B. The Bragg peak generated by carbon ions is sharper than that of protons, which may lead to a higher incident dose (23). In addition, a more pronounced "tail" can usually be observed behind the carbon ion range because nuclear interactions cause the carbon ions to break down into lighter particles (17). The penumbra of the high-energy proton beam is about $15 \mathrm{~cm}$ narrower than the penumbra of the X-ray beam. Compared with the former two qualities is heavier carbon ions, which makes carbon ion beam lateral scattering is smaller, and the corresponding penumbra area more acute, the closer the penumbra makes them maintain their direction when targeting tumor, further improve the accuracy of radiation, this will also help narrow pencil beam scanning control points better. In the longitudinal direction, carbon ions showed a more drastic dose drop than protons. The Bragg peak of the carbon ion beam enables it to provide most of the dose at the end of the range (Bragg peak), followed by almost no dose, leading to better normal tissue around the tumor area. However, because the tumor size is usually wider than the Bragg peak, the researchers developed different techniques to overlay the Bragg peak at different depths to form a SOBP that covers the entire tumor area and is evenly exposed to radiation. The carbon ions in SOBP energy can increase the energy of the body surface and the normal tissues in front of the tumor, but the energy of the normal tissues behind the tumor is still very low.

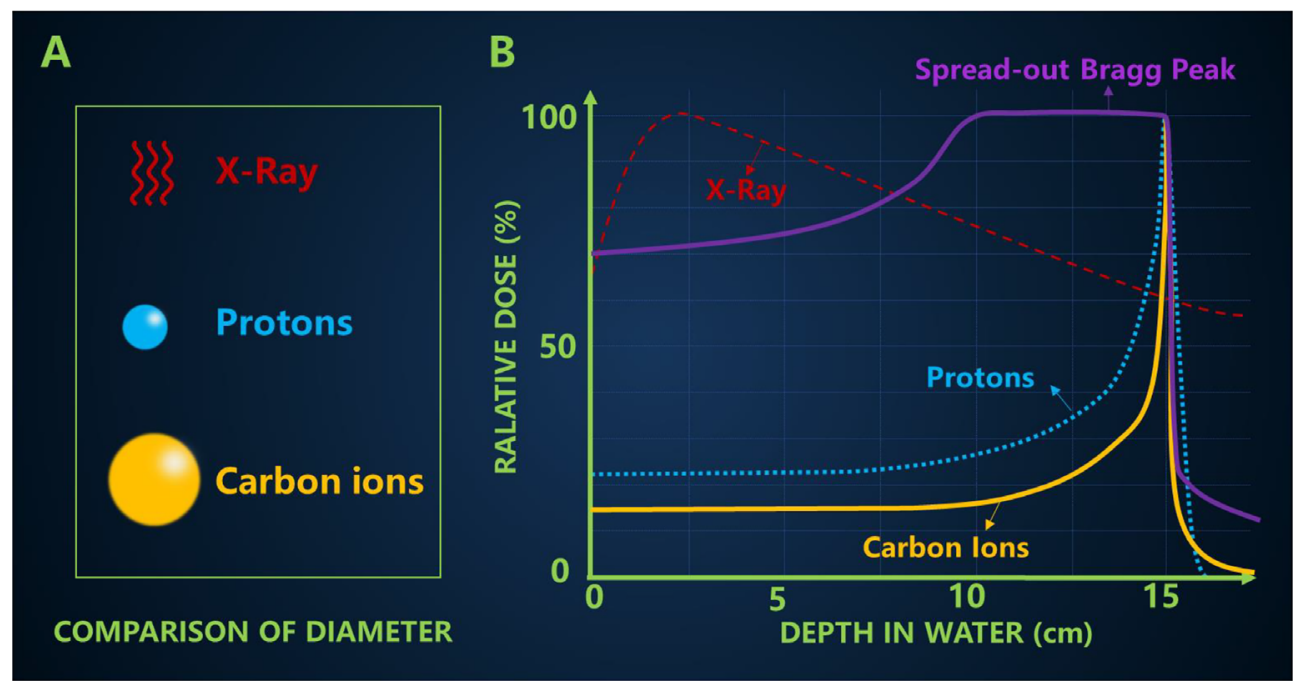

FIGURE 3 | (A) Comparison of particle size (B) The typical depth dose curves of X-ray, protons and carbon ion beams, and a spread-out Bragg peak (SOBP) created by super-positioning many Bragg peaks at different depths. 
Osama believed that carbon ions caused cluster damage to DNA, both in terms of the high energy of carbon ions directly killing tumor cells and the complexity of indirect damage caused by ROS produced during the killing process, which made DNA repair difficult to achieve (6). Moreover, the higher the LET, the larger the DSBs, and the more the aggregation, and the more complex the DSBs, so as to promote carbon ions to cause a powerful lethal effect on cancer cells (24). A study from The University of Queensland has shown that CIRT induces more complex DSB, larger foci and more concentrated 53BP1 foci. Compared with $\mathrm{x}$ rays, CIRT caused greater differences in gene expression (25). CIRT can also induce irreparable DSBs, leading to increased cell killing from stem and non-stem cells (26) and from neuroblastoma and glioblastoma cell lines in patients with central nervous system (CNS) glioma. A study investigating the risk of secondary malignancy in prostate cancer patients found a lower risk of CIRT use due to reduced exposure to normal tissue using CIRT outside the target area (27). In addition, CIRT is one of the superior non-invasive methods for treating tumors in dangerous organs (such as heart and lung) and tumors resistant to conventional radiotherapy, while also allowing for combination therapy of target volumes, thereby increasing treatment rates. Clinical data of local recurrence of some gastrointestinal tumors, especially rectal cancer and pancreatic cancer, have been reported (28). Table 2 provides a comparison of X-ray, proton, and carbon-based radiotherapy.

\section{Shortcomings and Problems \\ The Technique Is Difficult and the Parameters Are Uncertain}

Improving the biological effects of cancer therapy while reducing the dose to healthy tissue is a challenge. Compared to X-rays, beams of carbon ions are very sensitive to distance errors, which can lead to significant overdose or underdose. In addition, Bragg Peak is more likely to exist in a normal organization within a movement. The CIRT also shows a fragmented tail, causing greater uncertainty to the distal target tissue. Planning target volume (PTV) (suggested by ICRU report 50) has long been used to address the uncertainty of parameters during radiotherapy setting. The treatment plan of CIRT is designed based on the anatomical information obtained by the patient from the X-ray generated CT image. A margin of 3-6 mm is usually added to the clinical target volume (CTV) of PTV. However, this derivation is not accurate, and the error can reach $5 \mathrm{~mm}$ even within the range of $10 \mathrm{~cm}$ particles. For example, in 2016, Karasawa used carbon ions to treat head and neck cancer, where they added a $5 \mathrm{~mm}$ margin to the CTV to ensure that the skin dose did not exceed 30 Gy (RBE) per week and was less than $50 \%$ of the prescribed dose (29). While, in 2017, Romeser used proton therapy for recurrent head and neck cancer increased the margin for PTV by $3 \mathrm{~mm}$ and added 10-20Gy (RBE) to the brain stem, spinal cord, and optic nerve structures, according to the interval since prior RT (30). In order to solve this uncertainty, people usually adopt optimized treatment regimens, such as setting the maximum tolerance value (31). However, when critical structures are very close to the target volume, consideration of these uncertainties may significantly affect the dose-shaping ability of using a carbon ion beam.

\section{Lack of Data and Unclear Mechanism}

Compared with X-ray treatment, CIRT treatment is still in the exploratory stage, with millions or more patients treated with $\mathrm{X}$ ray, but only a few tens of thousands of cases treated with CIRT. As a result, the clinical data of CIRT is limited, and many problems in the treatment process are still to be solved. In addition, many of the biological mechanisms of carbon ion therapy remain uncertain. The exact extent and quality of the biological effects of carbon ions along its path, for example, remains uncertain. This uncertainty is caused by the special radiobiological properties of densely ionized heavy ion orbitals, which may be a problem of toxicity in normal tissues. At the same time, although the current reports do not find secondary cancer, but may have a long incubation period, this is still a problem to be considered. CIRT is rarely used, is still considered "experimental" for many tumor sites, and guidelines for clinical indications are still being established $(11,28)$. It is not yet possible to draw conclusions about its efficacy or toxicity, and further studies are needed to obtain more reliable data on its efficacy and toxicity.

TABLE 2 | Comparison between X-ray, proton, and carbon-based radiotherapy.

\begin{tabular}{|c|c|c|c|}
\hline Parameter & Carbon lons & Protons & X-ray \\
\hline Year of First Treatment & 1994 & 1954 & Late 1800 s and Early 1900s \\
\hline Number of Sites Treating (Last Update: Sep 2020) & 12 & 97 & Routine \\
\hline Worldwide treated patients, estimate & $30,000^{\#}$ & $190,000^{\#}$ & Millions \\
\hline Volume of irradiated normal tissue & Smallest & Small & Large \\
\hline Bragg-Peak & Present & Present & Absent \\
\hline Estimated RBE & $1.1-5.0$ & 1.1 & 1.0 \\
\hline Relative LET & Highest & High & Low \\
\hline Targeting precision & Highest & High & Low \\
\hline In tumor tissue & High & Low & Low \\
\hline In normal tissue & Low & Low & Low \\
\hline Relative Risk of Secondary Malignancy & Low & Low & High \\
\hline System cost & Highest & High & Low \\
\hline
\end{tabular}

${ }^{\#}$ Dates from Particle Therapy Co-Operative Group. 


\section{High Cost, Difficult to Promote}

Despite CIRT's advantages and promising preclinical and clinical data to date, the cost of the carbon-based device is high due to the complexity of the system, such as the need for a synchrotron and additional shielding, and the cost-effectiveness of this expensive treatment remains unclear. So there are only a few institutions around the world that do CIRT. According to PTCOG, only 12 organizations are using carbon ions. The biggest obstacle to the widespread use of CIRT is the high initial investment in $\mathrm{c}$ ion centers and the high cost of maintenance and treatment, which makes it impossible for most hospitals and universities to set up c ion centers. Only a few studies have assessed the costeffectiveness of CIRT.

\section{CLINICAL EXPERIENCES WITH CIRT}

As mentioned above, $\mathrm{C}$-ions have unique physical biological properties that have the potential to be ideal heavy particle candidates for cancer therapy. In addition to this, CIRT has significant capacity and potential to overcome DNA repair mechanisms. Moreover, many CIRT modalities involve hypo fractionation, which improves treatment efficiency and costeffectiveness $(32,33)$. Table 3 summarizes the current representative clinical trials based on CIRT therapy, including the related clinical data, including the organization, central location, types of cancer and primary end-point or results and so on. Clinical data obtained so far show that even tumors that are difficult to treat, such as those that are deep, critical, traditionally considered radiation-resistant, or recurrent and highly invasive, the results are reasonable (28).

In order to better and more intuitively understand the current status of heavy ion therapy, we made statistics on the data of National Institutes for Quantum and Radiological Science and Technology and Shanghai Proton Heavy Ion Hospital, respectively. According to relevant data of the National Institutes for Quantum and Radiological Science and Technology (website: www.qst.go.jp.) relevant data, in which there were about 11,834 patients who using CIRT alone or in combination with other treatment modalities, from the start of clinical trials in June 1994 to March 2019. The annual number of patients treated with heavy ions and the distribution of heavy ion radiotherapy in Japan's NIRS for various cancer patients, and among the admitted patients, prostate cancer was $27.8 \%$, bone and soft tissue tumors $10.7 \%$, head and neck cancer $10.1 \%$, lung cancer $8.9 \%$, pancreatic cancer $5.9 \%$, Liver cancer was $5.2 \%$, rectal cancer was $5.1 \%$ (Figure 4). The annual number of patients treated with heavy ion therapy alone or PT alone or heavy ion combined with PT in Shanghai Proton Heavy Ion Hospital for various cancer patients. By September 30, 2020, Shanghai Proton Heavy Ion Hospital has treated more than 3,000 discharged patients, with an average annual growth rate of 28\% (website: www.sphic.org.cn). Among them, a total of 2836 patients were treated with heavy ion therapy alone or combined with heavy ion proton therapy (1083 cases with heavy ion therapy, 1753 cases with heavy ion combined with PT), accounting for $94.5 \%$, making full use of and giving full play to the advantages of heavy ion therapy technology. Recently, the treatment volume of monomer heavy ion in this treatment facility has been maintained at about 80 treatments, and the preparation time before admission has been shortened by 10.4 days. Among the 3,000 patients who had been treated and discharged from hospital, 1,539 cases were head and neck tumors, including 618 cases of nasopharyngeal cancer, 119 cases of chordoma, 56 cases of meningioma, 88 cases of glioma, 175 cases of adenoid cystic carcinoma, 83 cases of sarcoma and chondrosarcoma, and 400 other cases. There were 518 cases of breast tumor, including 381 cases of lung cancer, 32 cases of esophageal cancer, 29 cases of thymic carcinoma and 76 other cases. There were 943 cases of tumors in the abdomen and pelvis and other areas, including 264 cases of prostate cancer, 120 cases of liver cancer, 130 cases of pancreatic cancer, 136 cases of breast cancer, 16 cases of gallbladder, 44 cases of cervical cancer, 42 cases of recur rectal cancer after surgery, and 191 other cases. Guided by patient needs, Shanghai Proton Heavy Ion Hospital conducts clinical treatment centering on five key diseases with the highest incidence in China, including nasopharyngeal cancer, cranial base tumor, lung cancer, liver cancer and prostate cancer, and conducts key clinical research on pancreatic cancer, with the number of patients with key diseases accounting for $64 \%$ of the total (Figure 5). A summary of selected clinical outcomes for treatment of kinds of cancers with CIRT is in Table 4. It can be seen that CIRT is effective and safe for most cancers, and is less toxic.

\section{SENSITIZING AGENT}

CIRT therapy has significant advantages over other approaches to treating cancer, but it still has a lot of room for improvement. Meanwhile, Increasing the maximum dose accumulation in tumor tissues while also looking to reduce the damage to normal tissues has always been a great challenge in radiotherapy. Different treatment strategies have been proposed to balance treatment outcomes with side effects, such as reversing radiation resistance of tumor tissue, increasing radiation sensitization of tumor tissue, and limiting the deposition of radiation dose in tumor volume (78). Current efforts are being made to achieve the goal of improving the biological effects of carbon ion irradiation by using approaches such as cellular pathway inhibitors (79), small chemical drugs $(80,81)$, and metallic nanomaterials $(82,83)$. Among them, sensitized agents (usually nanomaterials) refer to chemical or biological compounds that enhance the effective dose of RT on cancer cells, either through increased permeability and retention effects or through the use of targeted biomolecules that accumulate in tumors. It has been developed as a nanoenhancer to increase the physical irradiation dose of biological effects, which has attracted wide attention $(84,85)$.

Due to the high cost of carbocation therapy, its application is few, and the related sensitizing agent research is very rare. According to research, only a few metal nanoparticles have 
TABLE 3 | A list of selected open and/or recruiting clinical trials using CIRT alone or in combination with other treatment modalities.

\begin{tabular}{|c|c|c|c|c|c|c|}
\hline \multirow[t]{2}{*}{ No. } & \multirow[t]{2}{*}{$\begin{array}{l}\text { Organization, Central } \\
\text { Location }\end{array}$} & \multirow[t]{2}{*}{ Cancer } & \multirow[t]{2}{*}{ Trial Arms } & \multirow[t]{2}{*}{$\begin{array}{l}\text { Recruitment } \\
\text { status }\end{array}$} & \multirow[t]{2}{*}{$\begin{array}{l}\text { Target } \\
\text { sample } \\
\text { size }\end{array}$} & \multirow[t]{2}{*}{ Primary end-point or Results } \\
\hline & & & & & & \\
\hline 1 & NIRS, Japan & Pancreatic cancer & / & $\begin{array}{l}\text { No longer } \\
\text { recruiting }\end{array}$ & 46 & 3-year overall survival \\
\hline 2 & & Liver tumor & / & $\begin{array}{l}\text { No longer } \\
\text { recruiting }\end{array}$ & 50 & Overall survival \\
\hline 3 & & $\begin{array}{l}\text { Sinonasal and oral } \\
\text { cavity cancers }\end{array}$ & / & Completed & 60 & Development of oronasal fistula \\
\hline 4 & & $\begin{array}{l}\text { Malignant tumor of } \\
\text { sphenoid sinus }\end{array}$ & / & Completed & 20 & $\begin{array}{l}\text { Overall survival; } \\
\text { Local control; } \\
\text { Late toxicity }\end{array}$ \\
\hline 5 & & $\begin{array}{l}\text { Recurrent head } \\
\text { and neck tumors }\end{array}$ & / & Completed & 48 & $\begin{array}{l}\text { The } 2 \text {-year local control, loco regional control, progression- } \\
\text { free survival, and overall survival rates were } 40.5,33.5 \% \text {, } \\
29.4 \% \text {, and } 59.6 \% \text {, respectively. }\end{array}$ \\
\hline 6 & & $\begin{array}{l}\text { Renal cell } \\
\text { carcinoma }\end{array}$ & $\begin{array}{l}\text { Single arm: } \\
\text { Carbon ion (16 or } \\
12 \text { fractions) }\end{array}$ & Completed & 27 & Safety \\
\hline 7 & & $\begin{array}{l}\text { The lacrimal gland } \\
\text { carcinoma }\end{array}$ & / & Completed & 33 & $\begin{array}{l}\text { Local control rates } 62 \%(5 \mathrm{yr}) \\
\text { Overall survival rates }(65 \%)\end{array}$ \\
\hline 8 & & $\begin{array}{l}\text { Stage I non-small } \\
\text { cell lung cancer }\end{array}$ & $\begin{array}{l}\text { Single arm: } \\
\text { Carbon ion } \\
\text { (single fractions) }\end{array}$ & Unpublished & 200 & $\begin{array}{l}\text { Local control; } \\
\text { Overall survival }\end{array}$ \\
\hline 9 & & $\begin{array}{l}\text { Mucosal Malignant } \\
\text { Melanoma of the } \\
\text { Head and Neck }\end{array}$ & / & Completed & 100 & $\begin{array}{l}\text { Local control; } \\
\text { Overall survival }\end{array}$ \\
\hline 10 & & $\begin{array}{l}\text { Lung cancer or } \\
\text { metastatic lung } \\
\text { tumor }\end{array}$ & / & Completed & 95 & $\begin{array}{l}\text { Toxicity; } \\
\text { Local control rates 54\% (2 yr); } \\
\text { Overall survival rate } 61.9 \% \text { (2 yr) }\end{array}$ \\
\hline 11 & & Oral malignancies & $\begin{array}{l}\text { Single arm: } \\
\text { Carbon ion }\end{array}$ & Completed & 83 & $\begin{array}{l}\text { Local control, progression free survival rates, and overall } \\
\text { survival }\end{array}$ \\
\hline 12 & & $\begin{array}{l}\text { Skull base and } \\
\text { upper cervical } \\
\text { spine chordoma }\end{array}$ & $\begin{array}{l}\text { Single arm: } \\
\text { Carbon ion }\end{array}$ & Completed & 51 & $\begin{array}{l}\text { Local control } \\
\text { Overall survival }\end{array}$ \\
\hline 13 & & $\begin{array}{l}\text { Malignancy } \\
\text { located chest or } \\
\text { abdomen }\end{array}$ & $\begin{array}{l}\text { Single arm: } \\
\text { Carbon ion }\end{array}$ & Completed & 10 & Acute adverse reaction \\
\hline 14 & & $\begin{array}{l}\text { Metastatic lung } \\
\text { tumor }\end{array}$ & $\begin{array}{l}\text { Single arm: } \\
\text { Carbon ion (1-26 } \\
\text { fractions) }\end{array}$ & Completed & 100 & $\begin{array}{l}\text { Local control rates } 79.9 \% \text { (5 yr); } \\
\text { Overall survival rate } 58.9 \% \text { (5 yr) }\end{array}$ \\
\hline 15 & & $\begin{array}{l}\text { Solitary lymph } \\
\text { node recurrence }\end{array}$ & $\begin{array}{l}\text { Single arm: } \\
\text { Carbon ion }\end{array}$ & Unpublished & 310 & $\begin{array}{l}\text { 2-year local control } \\
\text { Incidence of grade } 2 \text { or worse late toxicities }\end{array}$ \\
\hline 16 & & Pancreatic cancer & $\begin{array}{l}\text { Single arm: } \\
\text { Carbon ion (12 } \\
\text { fractions) }\end{array}$ & $\begin{array}{l}\text { Open public } \\
\text { recruiting }\end{array}$ & 24 & $\begin{array}{l}\text { Rate of grade } 3-5 \text { acute toxicity } \\
\text { Overall survival, local control }\end{array}$ \\
\hline 17 & & Kinds of cancer & / & $\begin{array}{l}\text { Enrolling by } \\
\text { invitation }\end{array}$ & 999 & Overall survival \\
\hline 18 & & $\begin{array}{l}\text { Primary pancreatic } \\
\text { cancer }\end{array}$ & $\begin{array}{l}\text { Single arm: } \\
\text { Carbon ion }\end{array}$ & Terminated & 10 & Acute normal tissue damages \\
\hline 19 & & $\begin{array}{l}\text { Adenoid cystic } \\
\text { carcinoma }\end{array}$ & $\begin{array}{l}\text { Single arm: } \\
\text { Carbon ion }\end{array}$ & Completed & 100 & $\begin{array}{l}\text { Toxicities (acute and late) } \\
5 \text {-year overall survival }\end{array}$ \\
\hline 20 & & $\begin{array}{l}\text { Mucosal malignant } \\
\text { melanoma }\end{array}$ & $\begin{array}{l}\text { Single arm: } \\
\text { Carbon ion }\end{array}$ & Completed & 20 & 5-year overall survival \\
\hline 21 & & $\begin{array}{l}\text { Pelvic recurrent } \\
\text { rectal cancer }\end{array}$ & $\begin{array}{l}\text { Single arm: } \\
\text { Carbon ion (16 } \\
\text { fractions) }\end{array}$ & $\begin{array}{l}\text { Open public } \\
\text { recruiting }\end{array}$ & 71 & 3-year overall survival \\
\hline 22 & & $\begin{array}{l}\text { Malignant tumor } \\
\text { located in thorax } \\
\text { or abdomen }\end{array}$ & Single arm & Completed & 12 & $\begin{array}{l}\text { Acute toxicity } \\
\text { Initial response of local tumor }\end{array}$ \\
\hline 23 & & Breast cancer & $\begin{array}{l}\text { Single arm: } \\
\text { Carbon ion (4 } \\
\text { fractions) }\end{array}$ & $\begin{array}{l}\text { Open public } \\
\text { recruiting }\end{array}$ & 20 & Acute toxicities of normal tissue \\
\hline 24 & & Malignant tumor & Single arm & Completed & 15 & Acute radiation toxicity \\
\hline
\end{tabular}


TABLE 3 | Continued

\begin{tabular}{|c|c|c|c|c|c|c|}
\hline \multirow[t]{2}{*}{ No. } & \multirow[t]{2}{*}{$\begin{array}{l}\text { Organization, Central } \\
\text { Location }\end{array}$} & Cancer & \multirow[t]{2}{*}{ Trial Arms } & \multirow[t]{2}{*}{$\begin{array}{l}\text { Recruitment } \\
\text { status }\end{array}$} & \multirow[t]{2}{*}{$\begin{array}{l}\text { Target } \\
\text { sample } \\
\text { size }\end{array}$} & \multirow[t]{2}{*}{ Primary end-point or Results } \\
\hline & & Histology/Site & & & & \\
\hline 25 & & $\begin{array}{l}\text { Head and neck } \\
\text { cancer except } \\
\text { sarcoma }\end{array}$ & $\begin{array}{l}\text { Single arm: } \\
\text { Carbon ion }\end{array}$ & Completed & 1000 & $\begin{array}{l}\text { Overall survival } \\
\text { Local control }\end{array}$ \\
\hline 26 & & Pancreatic Cancer & $\begin{array}{l}\text { Single arm: } \\
\text { Carbon ion (8 } \\
\text { fractions) }\end{array}$ & $\begin{array}{l}\text { Open public } \\
\text { recruiting }\end{array}$ & 10 & Acute toxicity of organ at risks \\
\hline 27 & & Renal Cancer & $\begin{array}{l}\text { Single arm: } \\
\text { Carbon ion }\end{array}$ & / & 10 & Acute radiation toxicity of normal tissue \\
\hline 28 & & Prostate cancer & $\begin{array}{l}\text { Single arm: } \\
\text { Carbon ion (12 } \\
\text { fractions) }\end{array}$ & $\begin{array}{l}\text { No longer } \\
\text { recruiting }\end{array}$ & 45 & Incidence of late radiation toxicity \\
\hline 29 & & $\begin{array}{l}\text { Locally advanced } \\
\text { adenocarcinoma } \\
\text { of the uterine } \\
\text { cervix }\end{array}$ & $\begin{array}{l}\text { Single arm: } \\
\text { Carbon ( } 20 \\
\text { fractions) }\end{array}$ & $\begin{array}{l}\text { Open public } \\
\text { recruiting }\end{array}$ & 32 & $\begin{array}{l}\text { Phase I study } \\
\text { Acute toxicity }\end{array}$ \\
\hline 30 & $\begin{array}{l}\text { University of Texas } \\
\text { Southwestern Medical Center, } \\
\text { Department of Radiation } \\
\text { Oncology Dallas, USA }\end{array}$ & $\begin{array}{l}\text { Locally advanced, } \\
\text { unresectable } \\
\text { pancreatic cancer }\end{array}$ & $\begin{array}{l}\text { Arm 1: Carbon } \\
\text { ion } \\
\text { Arm 2: } \\
\text { Chemotherapy }\end{array}$ & Completed & 103 & 2-year overall survival \\
\hline 31 & & $\begin{array}{l}\text { Locally Advanced } \\
\text { Pancreatic } \\
\text { Adenocarcinoma }\end{array}$ & $\begin{array}{l}\text { Arm 1: Carbon } \\
\text { ion } \\
\text { Arm 2: Photon }\end{array}$ & $\begin{array}{l}\text { Active, not } \\
\text { recruiting }\end{array}$ & 110 & 2-year overall survival \\
\hline 32 & $\begin{array}{l}\text { Gunma University, Heavy lon } \\
\text { Medical Center Gunma, Japan }\end{array}$ & Prostate cancer & $\begin{array}{l}\text { Single arm: } \\
\text { Carbon ion (12 } \\
\text { fractions) }\end{array}$ & $\begin{array}{l}\text { No longer } \\
\text { recruiting }\end{array}$ & 300 & Expanded prostate cancer index composite (epic) \\
\hline 33 & & $\begin{array}{l}\text { Prostate, } \\
\text { pancreatic, or } \\
\text { uterine cancer }\end{array}$ & $\begin{array}{l}\text { Single arm: } \\
\text { Carbon ion }\end{array}$ & Completed & 30 & $\begin{array}{l}\text { To evaluate tumor movement using } \mathrm{CT} \text { images acquired on } \\
\text { the treatment days and the treatment planning CT images. }\end{array}$ \\
\hline 34 & & $\begin{array}{l}\text { Head and neck } \\
\text { cancer }\end{array}$ & $\begin{array}{l}\text { Single arm: } \\
\text { Carbon ion }\end{array}$ & $\begin{array}{l}\text { Open public } \\
\text { recruiting }\end{array}$ & 43 & Dermatitis, microsites, QOL \\
\hline 35 & & $\begin{array}{l}\text { Lung or Liver } \\
\text { cancer }\end{array}$ & $\begin{array}{l}\text { Single arm: } \\
\text { Carbon ion }\end{array}$ & $\begin{array}{l}\text { Open public } \\
\text { recruiting }\end{array}$ & 20 & $\begin{array}{l}\text { To evaluate tumor movement using CT images acquired on } \\
\text { the treatment days and the treatment planning CT images. }\end{array}$ \\
\hline 36 & & $\begin{array}{l}\text { Head and neck } \\
\text { cancer }\end{array}$ & $\begin{array}{l}\text { Single arm: } \\
\text { Carbon ion }\end{array}$ & Preinitiation & 40 & Dermatitis/microsites \\
\hline 37 & & $\begin{array}{l}\text { Locally advanced } \\
\text { pancreatic cancer }\end{array}$ & $\begin{array}{l}\text { Single arm: } \\
\text { Carbon (12 } \\
\text { fractions) }\end{array}$ & - & 20 & 2-year overall survival \\
\hline 38 & & $\begin{array}{l}\text { Hepatocellular } \\
\text { carcinoma }\end{array}$ & $\begin{array}{l}\text { Single arm: } \\
\text { Carbon ion (4 } \\
\text { fractions) }\end{array}$ & $\begin{array}{l}\text { No longer } \\
\text { recruiting }\end{array}$ & 35 & 3-year local control \\
\hline 39 & & $\begin{array}{l}\text { Hepatocellular } \\
\text { carcinoma }\end{array}$ & $\begin{array}{l}\text { Single arm: } \\
\text { Carbon ion ( } 4 \text { or } \\
12 \text { fractions) }\end{array}$ & $\begin{array}{l}\text { Open public } \\
\text { recruiting }\end{array}$ & 130 & 3-year overall survival \\
\hline 40 & & $\begin{array}{l}\text { Hepatocellular } \\
\text { carcinoma }\end{array}$ & / & Completed & 250 & Overall survival \\
\hline 41 & & $\begin{array}{l}\text { Primary liver } \\
\text { cancer }\end{array}$ & $\begin{array}{l}\text { Single arm: } \\
\text { Carbon ion (12 } \\
\text { fractions) }\end{array}$ & Completed & 6 & Dose-limiting toxicity \\
\hline 42 & & $\begin{array}{l}\text { Hepatocellular } \\
\text { carcinoma }\end{array}$ & $\begin{array}{l}\text { Single arm: } \\
\text { Carbon ion (4 } \\
\text { fractions) }\end{array}$ & Completed & 3 & Acute toxicity \\
\hline 43 & & $\begin{array}{l}\text { Recurrent tumor in } \\
\text { previously } \\
\text { irradiated site }\end{array}$ & $\begin{array}{l}\text { Single arm: } \\
\text { Carbon ion }\end{array}$ & $\begin{array}{l}\text { Open public } \\
\text { recruiting }\end{array}$ & 30 & 1-year local control \\
\hline 44 & & $\begin{array}{l}\text { Refractory } \\
\text { malignant tumor }\end{array}$ & $\begin{array}{l}\text { Single arm: } \\
\text { Carbon ion }\end{array}$ & $\begin{array}{l}\text { Open public } \\
\text { recruiting }\end{array}$ & 50 & 1-year local control \\
\hline 45 & & $\begin{array}{l}\text { Lymph-node } \\
\text { recurrence of } \\
\text { malignant tumors }\end{array}$ & $\begin{array}{l}\text { Single arm: } \\
\text { Carbon ion (12 } \\
\text { fractions) }\end{array}$ & $\begin{array}{l}\text { Open public } \\
\text { recruiting }\end{array}$ & 20 & 2-year local control \\
\hline 46 & & & & Preinitiation & 25 & 3-year overall survival and cause-specific survival rate \\
\hline
\end{tabular}

(Continued) 
TABLE 3 | Continued

\begin{tabular}{|c|c|c|c|c|c|c|}
\hline \multirow[t]{2}{*}{ No. } & \multirow[t]{2}{*}{$\begin{array}{l}\text { Organization, Central } \\
\text { Location }\end{array}$} & & \multirow[t]{2}{*}{ Trial Arms } & \multirow[t]{2}{*}{$\begin{array}{l}\text { Recruitment } \\
\text { status }\end{array}$} & \multirow[t]{2}{*}{$\begin{array}{c}\text { Target } \\
\text { sample } \\
\text { size }\end{array}$} & \multirow[t]{2}{*}{ Primary end-point or Results } \\
\hline & & & & & & \\
\hline & & $\begin{array}{l}\text { Malignant } \\
\text { melanoma of head } \\
\text { and neck }\end{array}$ & $\begin{array}{l}\text { Single arm: } \\
\text { Carbon ion (16 } \\
\text { fractions) plus }\end{array}$ & & & \\
\hline 47 & & $\begin{array}{l}\text { Clinical stage III } \\
\text { non-small cell lung } \\
\text { cancer }\end{array}$ & Chemotherapy & / & $\begin{array}{l}\text { Open } \\
\text { public }\end{array}$ & recruiting \\
\hline / & & $\begin{array}{l}\text { Acute adverse } \\
\text { effect }\end{array}$ & & & & \\
\hline 48 & & Prostate cancer & $\begin{array}{l}\text { Single arm: } \\
\text { Carbon ion (16 } \\
\text { fractions) }\end{array}$ & Completed & 130 & Biochemical relapse-free rate at 5 years \\
\hline 49 & & $\begin{array}{l}\text { Clinical stage I } \\
\text { non-small cell lung } \\
\text { cancer }\end{array}$ & $\begin{array}{l}\text { Single arm: } \\
\text { Carbon ion ( } 4 \\
\text { fractions) }\end{array}$ & Completed & 40 & $\begin{array}{l}\text { The actuarial 2-year, 3-year, and 5-year local control rates } \\
\text { were } 91.2 \%, 88.1 \% \text {, and } 88.1 \% \text {, respectively. The actuarial } \\
\text { 2-year, 3-year, and 5-year overall survival rates were } \\
91.9 \%, 80.0 \% \text {, and } 74.9 \% \text {, respectively. }\end{array}$ \\
\hline 50 & & Pediatrics & $\begin{array}{l}\text { Single arm: } \\
\text { Carbon ion }\end{array}$ & $\begin{array}{l}\text { Open public } \\
\text { recruiting }\end{array}$ & 6 & Acute complication rate \\
\hline 51 & & $\begin{array}{l}\text { Head and neck } \\
\text { sarcoma }\end{array}$ & $\begin{array}{l}\text { Single arm: } \\
\text { Carbon ion }\end{array}$ & $\begin{array}{l}\text { Open public } \\
\text { recruiting }\end{array}$ & 15 & 3-year local control \\
\hline 52 & & $\begin{array}{l}\text { Primary skull base } \\
\text { tumor }\end{array}$ & $\begin{array}{l}\text { Single arm: } \\
\text { Carbon ion } 16 \\
\text { fractions) }\end{array}$ & $\begin{array}{l}\text { Open public } \\
\text { recruiting }\end{array}$ & 20 & 3-year local control \\
\hline 53 & Head and neck cancer & $\begin{array}{l}\text { Single arm: } \\
\text { Carbon ion }\end{array}$ & $\begin{array}{l}\text { Open public } \\
\text { recruiting }\end{array}$ & 30 & $\begin{array}{l}\text { 3-year } \\
\text { local } \\
\text { control }\end{array}$ & \\
\hline 54 & $\begin{array}{l}\text { Kanagawa Cancer Center, } \\
\text { Kanagawa Prefectural Hospital } \\
\text { Organization, lon-beam } \\
\text { Radiation Oncology Center }\end{array}$ & $\begin{array}{l}\text { Peripherally } \\
\text { located stage-I } \\
\text { non-small cell lung } \\
\text { cancer }\end{array}$ & $\begin{array}{l}\text { Single arm: } \\
\text { Carbon ion (12- } \\
16 \text { fractions) }\end{array}$ & $\begin{array}{l}\text { Open public } \\
\text { recruiting }\end{array}$ & 162 & $\begin{array}{l}\text { Proportion of patients who developed glade } 2 \text { or early } \\
\text { severe adverse events related to lung and skin }\end{array}$ \\
\hline 55 & Kanagawa, Japan & $\begin{array}{l}\text { Locally advanced } \\
\text { pancreatic cancer }\end{array}$ & $\begin{array}{l}\text { Single arm: } \\
\text { Carbon ion ( } 12 \\
\text { fractions) plus } \\
\text { Chemotherapy }\end{array}$ & $\begin{array}{l}\text { Open public } \\
\text { recruiting }\end{array}$ & 77 & Local control \\
\hline 56 & & $\begin{array}{l}\text { Patients with } \\
\text { Prostate Cancer of } \\
\text { Clinical Stage t1c- } \\
\text { T3NOMO }\end{array}$ & $\begin{array}{l}\text { Single arm: } \\
\text { Carbon ion (12 } \\
\text { fractions) }\end{array}$ & $\begin{array}{l}\text { No longer } \\
\text { recruiting }\end{array}$ & 689 & Biochemical progression-free survival at 5 years \\
\hline 57 & & $\begin{array}{l}\text { Hepatocellular } \\
\text { carcinoma }\end{array}$ & $\begin{array}{l}\text { Single arm: } \\
\text { Carbon ion ( } 2 \text { or } \\
4 \text { fractions) }\end{array}$ & $\begin{array}{l}\text { Open public } \\
\text { recruiting }\end{array}$ & 50 & 3-year local control \\
\hline 58 & & $\begin{array}{l}\text { Mucosal malignant } \\
\text { melanoma of the } \\
\text { head and neck }\end{array}$ & $\begin{array}{l}\text { Single arm: } \\
\text { Carbon ion ( } 16 \\
\text { fractions) } \\
\text { combined with } \\
\text { anti-tumor agents }\end{array}$ & $\begin{array}{l}\text { No longer } \\
\text { recruiting }\end{array}$ & 65 & 3-year overall survival \\
\hline 59 & & $\begin{array}{l}\text { Small-sized } \\
\text { peripheral non- } \\
\text { small cell lung } \\
\text { cancer with clinical } \\
\text { stage IA }\end{array}$ & $\begin{array}{l}\text { Arm 1: Carbon } \\
\text { ion } \\
\text { Arm 2: Surgical } \\
\text { resection }\end{array}$ & $\begin{array}{l}\text { Open public } \\
\text { recruiting }\end{array}$ & 525 & 5-year overall survival \\
\hline 60 & & $\begin{array}{l}\text { Non-squamous } \\
\text { cell carcinoma of } \\
\text { head and neck }\end{array}$ & $\begin{array}{l}\text { Single arm: } \\
\text { Carbon ion (16 } \\
\text { fractions) }\end{array}$ & $\begin{array}{l}\text { No longer } \\
\text { recruiting }\end{array}$ & 54 & 3-year local control \\
\hline 61 & & $\begin{array}{l}\text { Hepatocellular } \\
\text { Carcinoma }\end{array}$ & $\begin{array}{l}\text { Single arm: } \\
\text { Carbon ion ( } 2 \text { or } \\
4 \text { fractions) }\end{array}$ & $\begin{array}{l}\text { Open public } \\
\text { recruiting }\end{array}$ & 50 & 3-year local control \\
\hline 62 & & $\begin{array}{l}\text { Localized prostate } \\
\text { cancer }\end{array}$ & $\begin{array}{l}\text { Single arm: } \\
\text { Carbon ion (12 } \\
\text { fractions) }\end{array}$ & $\begin{array}{l}\text { No longer } \\
\text { recruiting }\end{array}$ & 145 & Biochemical progression-free survival at 5 years \\
\hline 63 & & & & & 145 & Biochemical progression-free survival at 5 years \\
\hline
\end{tabular}


TABLE 3 | Continued

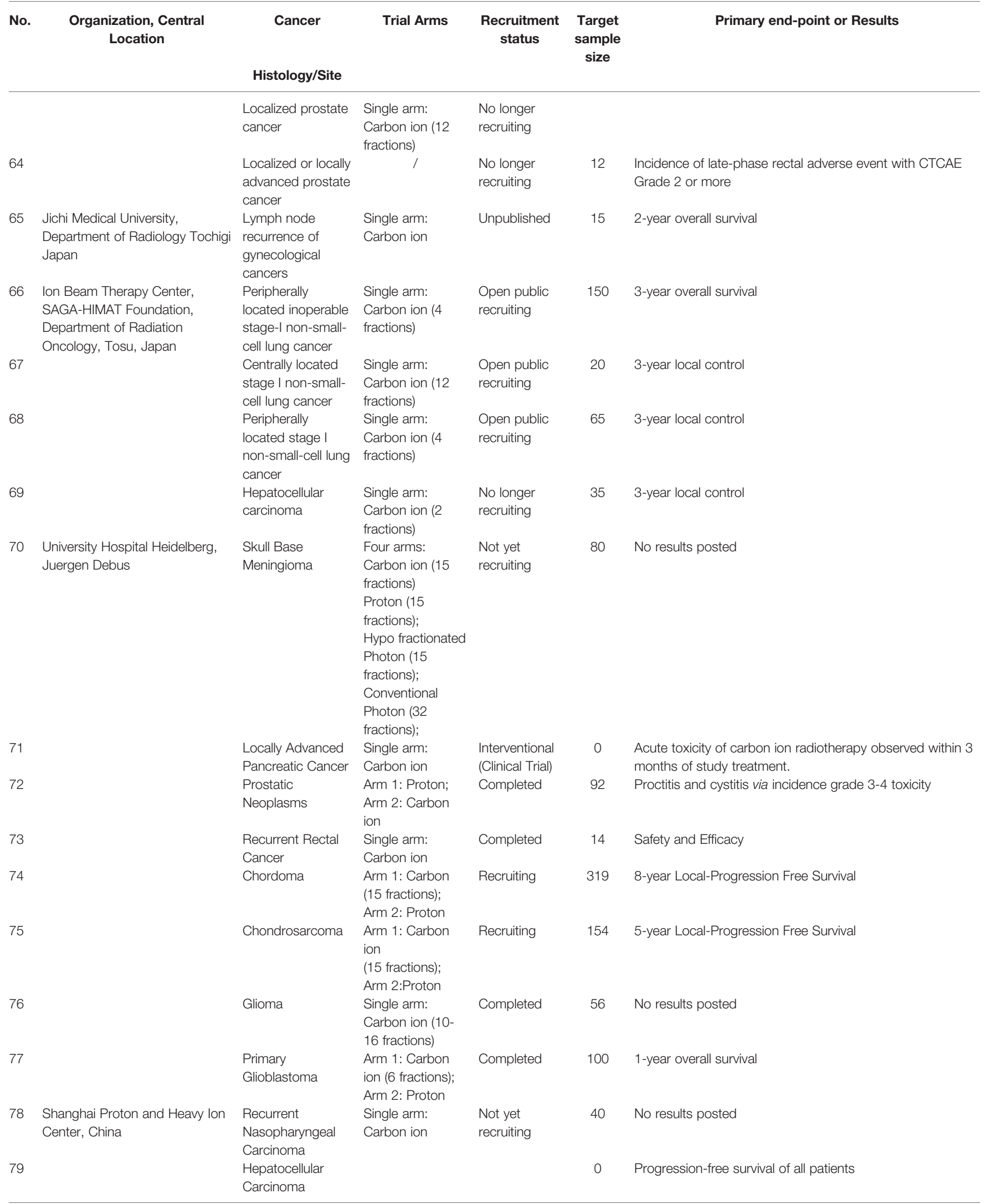


TABLE 3 | Continued

\begin{tabular}{|c|c|c|c|c|c|c|}
\hline \multirow[t]{2}{*}{ No. } & \multirow[t]{2}{*}{$\begin{array}{l}\text { Organization, Central } \\
\text { Location }\end{array}$} & \multirow{2}{*}{$\begin{array}{l}\text { Cancer } \\
\text { stology/Site }\end{array}$} & \multirow[t]{2}{*}{ Trial Arms } & \multirow[t]{2}{*}{$\begin{array}{l}\text { Recruitment } \\
\text { status }\end{array}$} & \multirow[t]{2}{*}{$\begin{array}{c}\text { Target } \\
\text { sample } \\
\text { size }\end{array}$} & \multirow[t]{2}{*}{ Primary end-point or Results } \\
\hline & & & & & & \\
\hline & & & $\begin{array}{l}\text { Single arm: } \\
\text { Carbon ion (5 } \\
\text { fractions) }\end{array}$ & $\begin{array}{l}\text { Withdrawn } \\
\text { (enrollment } \\
\text { was too slow) }\end{array}$ & & \\
\hline 80 & & $\begin{array}{l}\text { Adenoid Cystic } \\
\text { Carcinoma }\end{array}$ & $\begin{array}{l}\text { Arm 1: Carbon } \\
\text { ion; Arm 2: } \\
\text { Proton }\end{array}$ & Recruiting & 50 & No results posted \\
\hline 81 & & $\begin{array}{l}\text { Metastatic } \\
\text { Prostate } \\
\text { Carcinoma }\end{array}$ & $\begin{array}{l}\text { Carbon ion } \\
\text { radiotherapy } \\
\text { combined with } \\
\text { systemic therapy }\end{array}$ & Recruiting & 47 & Time to PSA relapse \\
\hline 82 & & $\begin{array}{l}\text { Hepatocellular } \\
\text { Carcinoma }\end{array}$ & $\begin{array}{l}\text { Single arm: } \\
\text { Carbon ion (10 } \\
\text { fractions) }\end{array}$ & Recruiting & 48 & $\begin{array}{l}\text { Number of participants with treatment-related adverse } \\
\text { events as assessed by CTCAE v4.0 }\end{array}$ \\
\hline 83 & & $\begin{array}{l}\text { Nasopharyngeal } \\
\text { Carcinoma }\end{array}$ & $\begin{array}{l}\text { Arm 1: Carbon } \\
\text { ion } \\
\text { Arm 2: } \\
\text { chemotherapy }\end{array}$ & $\begin{array}{l}\text { Terminated } \\
\text { (Slow accrual } \\
\text { of patients.) }\end{array}$ & 9 & No results posted \\
\hline 84 & & $\begin{array}{l}\text { Nasopharyngeal } \\
\text { Carcinoma }\end{array}$ & $\begin{array}{l}\text { Single arm: } \\
\text { Carbon ion }\end{array}$ & $\begin{array}{l}\text { Active, not } \\
\text { recruiting }\end{array}$ & 55 & No results posted \\
\hline 85 & & $\begin{array}{l}\text { Prostate } \\
\text { Carcinoma }\end{array}$ & $\begin{array}{l}\text { Single arm: } \\
\text { Carbon ion (16 } \\
\text { fractions) }\end{array}$ & Recruiting & 61 & $\begin{array}{l}\text { Number of participants with treatment-related adverse } \\
\text { events as assessed by CTCAE v4.0 }\end{array}$ \\
\hline 86 & & $\begin{array}{l}\text { Nasopharyngeal } \\
\text { Carcinoma }\end{array}$ & $\begin{array}{l}\text { Single arm: } \\
\text { Carbon ion }\end{array}$ & $\begin{array}{l}\text { Terminated } \\
\text { (Slow accrual } \\
\text { of patients.) }\end{array}$ & 9 & $\begin{array}{l}\text { Number of participants with treatment-related adverse } \\
\text { events as assessed by CTCAE v4.0 }\end{array}$ \\
\hline 87 & $\begin{array}{l}\text { Albert Einstein College of } \\
\text { Medicine, Nitin Ohri }\end{array}$ & Pancreatic Cancer & $\begin{array}{l}\text { Arm 1: Carbon } \\
\text { ion }\end{array}$ & Completed & 14 & $\begin{array}{l}\text { Dose-limiting toxicity } \\
\text { Any CTCAE v. } 4.03 \text { non-hematologic adverse event of } \\
\text { grade } 3 \text { or higher or any hematologic adverse event of } \\
\text { grade } 4 \text { or higher, occurring within } 90 \text { days of the start of } \\
\text { radiotherapy and deemed to be related to carbon ion } \\
\text { radiotherapy. }\end{array}$ \\
\hline 88 & European Institute of Oncology & $\begin{array}{l}\text { Adenocarcinoma } \\
\text { of Prostate }\end{array}$ & $\begin{array}{l}\text { Arm 1: Carbon } \\
\text { ion; Arm 2: } \\
\text { Proton }\end{array}$ & Recruiting & 65 & There were level 3 or level 4 adverse events \\
\hline 89 & Hospices Civils de Lyon & $\begin{array}{l}\text { Malignant Tumors } \\
\text { as Chordoma, } \\
\text { Adenoid Cystic } \\
\text { Carcinoma and } \\
\text { Sarcoma }\end{array}$ & $\begin{array}{l}\text { Arm 1: Carbon } \\
\text { ion; Arm 2: } \\
\text { X-rays and/or } \\
\text { protons }\end{array}$ & Recruiting & 250 & 5-year Progression free survival \\
\hline
\end{tabular}

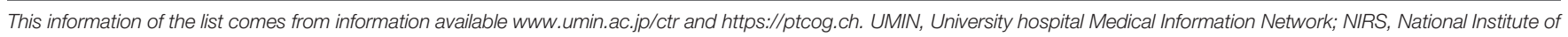
Radiological Sciences.

been used to improve carbon ion irradiation. In this chapter, we combined existing reports and sensitizers commonly used in radiotherapy to review the research on carbon ion sensitizing agent, in order to provide some reference and inspiration for relevant researchers.

\section{Common Sensitizing Agent}

Chemotherapy sensitizing agents were the first group of sensitizing agents on the treatment of cancer. They were often combined with chemotherapy drugs to increase the effectiveness of chemotherapy. Common chemotherapy drugs are gemcitabine, docetaxel, pemetrexed, paclitaxel, and some platinums, including cisplatin, carboplatin, and some nedaplatin. While, due to the drug resistance of some tumors, chemotherapy drugs cannot successfully achieve the expected effect of tumor treatment, so some combination therapy through chemotherapeutic sensitizing agent [such as, lonidamine (8690), poloxamers, silibinin (91)], immune checkpoint inhibitors [such as PD-1 inhibitors, PD-L1 inhibitors (92)], enzyme related inhibitors [such as ribonucleotide reductase inhibitors, crizotinib (93)], as well as other tumor-related inhibitors have become a research hotspot.

High atomic element $(Z)$ nanomaterials, such as bismuth $(Z=83)$, gold $(Z=79)$, tungsten $(Z=74)$, tantalum $(Z=73)$, hafnium $(Z=72)$, tellurium $(Z=52)$, silver $(Z=47)$, are capable of increasing the production of secondary and Auger electrons, which in turn increases the generated ROS and enhances the deposition of radiation. These elements are also called "nano enhancers" and they have much higher mass-energy absorption coefficients than soft tissues $(94,95)$. Therefore, nanoparticles based on high altitude subordinal metal as ionizing radiation sensitizing materials are getting more and more attention. 


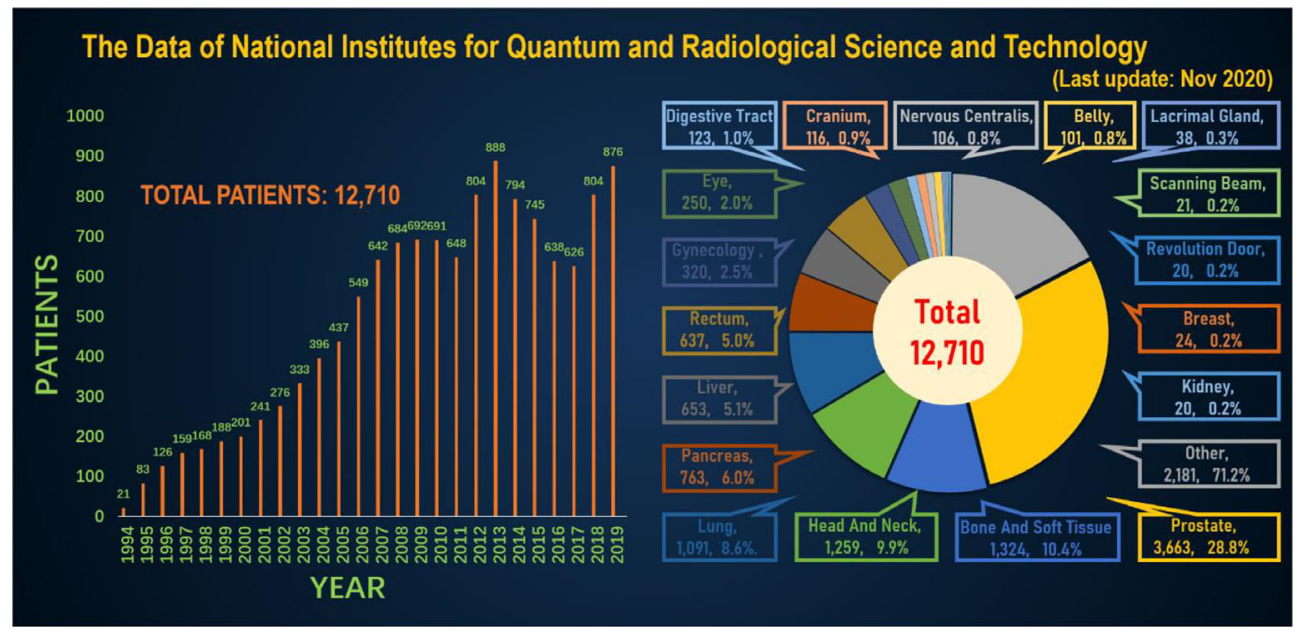

FIGURE 4 | The annual number of patients treated with heavy ions and the distribution of heavy ion radiotherapy in Japan's NIRS for various cancer patients.

Some of them also play a role in the treatment of cancer as the preparation nanomaterials of relatively common chemotherapeutic sensitizing agents, immune checkpoint inhibitors, enzyme-related inhibitors and tumor-related inhibitors, and some of them cooperate with other therapies as their sensitizing agents to achieve anti-cancer. In 2004, Hainfeld (96) reported for the first time that gold ( $\mathrm{Z}=79)$ nanoparticles could enhance the effect of tumor radiotherapy and inhibit tumor growth in vivo. Zhang (97) prepared gold nanoparticles coated with glutathione and composed of several gold atoms, which also confirmed this point. The author attributed its excellent targeting ability to good biocompatibility and ultrasmall particle size, and the results of tumor inhibition experiments also confirmed that "gold nanomolecules" had a good radiotherapy sensitization effect. Wang (98) constructed a kind of mesoporous silica $\left(\mathrm{SiO}_{2}\right)$ coated Janus gold nanorods. The unique structure of the material can on the one hand deposit the radiotherapy sensitization effect of the nanorods, and on the other hand can realize the efficient loading of doxorubicin as a chemotherapy drug. Chen designed a kind of Au@Se-R/A nanocomposite (Au@Se-R/A NCs) based on the radiotherapy sensitizer properties of gold nanorodes (NRs) and the antitumor activity of selenium NPs to realize synergistic chemoradiotherapy (99). Moreover, in vitro studies showed that the combined treatment of NCs and X-ray in A375 melanoma cells could significantly improve the anti-cancer efficacy by changing the expression of p53 and DNA damage genes, inducing cell apoptosis and triggering the excessive production of intracellular ROS. Subsequently, they synthesized a tellurium (Te, Z=52) nanosar (GTe-RGD),

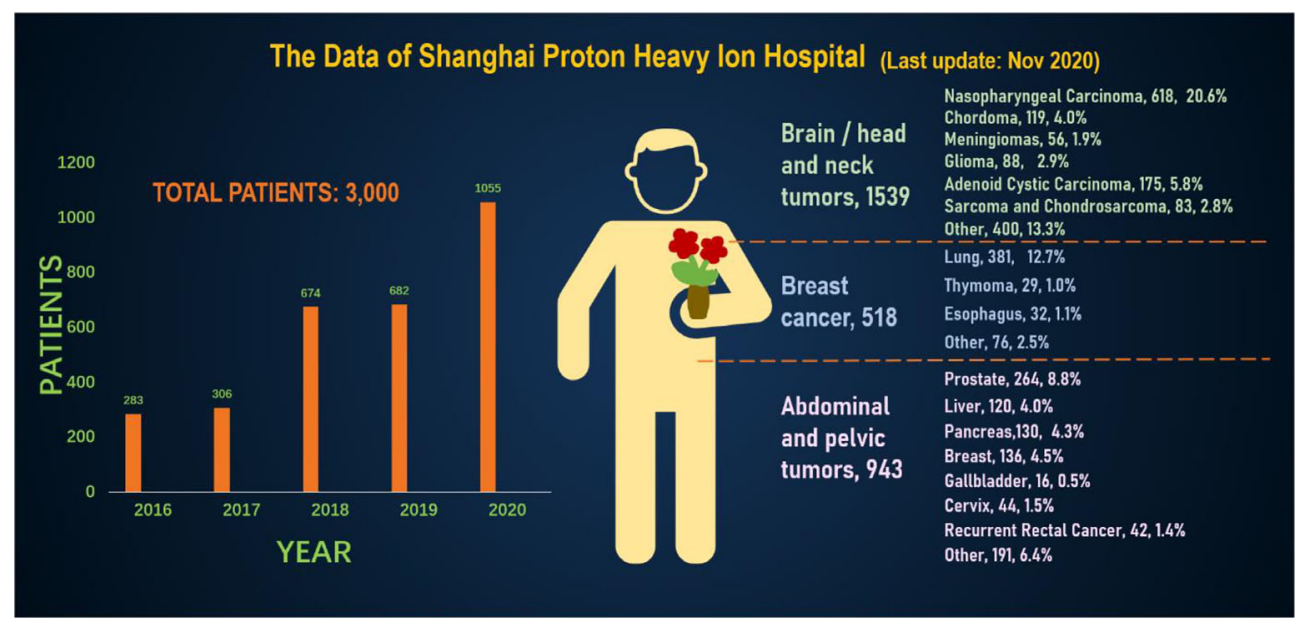

FIGURE 5 | The annual number of patients treated with heavy ion therapy alone or proton therapy alone or heavy ion combined with proton therapy in Shanghai Proton Heavy lon Hospital for various cancer patients. 
TABLE 4 | A summary of selected clinical outcomes for treatment of kinds of cancers with C-ion therapy.

\begin{tabular}{|c|c|c|c|c|c|}
\hline Cancer & $\begin{array}{l}\text { Patient } \\
\text { number }\end{array}$ & $\begin{array}{l}\text { Target } \\
\text { dose, } \\
\text { GyE }\end{array}$ & $\begin{array}{l}\text { Overall } \\
\text { survival }\end{array}$ & Local control & Late toxicity at reporting and results \\
\hline Recurrent NPC & 75 & $50-60$ & $\begin{array}{l}98.1 \%(1 \\
y r)\end{array}$ & $\begin{array}{l}\text { LRFS } 86.6 \%(1 \mathrm{yr}) \\
\text { RRFS } 97.9 \%(1 \mathrm{yr})\end{array}$ & 7 necrosis at tumor bed, including 1 carotid blowout (34). \\
\hline \multirow[t]{7}{*}{ STS } & 57 & $52.8-73.6$ & $\begin{array}{l}82 \%(1 \mathrm{yr}) \\
46 \%(3 \mathrm{yr})\end{array}$ & $88 \%(1 \mathrm{yr}) ; 73 \%$ (3 yr) & Without grade > 3 acute reactions. Effective and safe (35). \\
\hline & 24 & $52.8-73.6$ & $\begin{array}{l}75 \%(2 \mathrm{yr}) \\
50 \%(5 \mathrm{yr})\end{array}$ & $77 \%$ (2 yr); 69\% (5 yr) & No other toxicity greater than Grade 2 was observed. Effective and safe (36). \\
\hline & 78 & 70.4 & $33 \%(5 \mathrm{yr})$ & $62 \%(5 \mathrm{yr})$ & Toxicity occurs in individual patients. Effective and safe (37). \\
\hline & 17 & $52.8-70.4$ & $56 \%(5 \mathrm{yr})$ & $76 \%(5 \mathrm{yr})$ & Toxicity (grade 3) was not observed in most patients. Effective and safe (38). \\
\hline & 47 & $52.8-70.4$ & $52 \%(5 y r)$ & $79 \%(5 \mathrm{yr})$ & Without fatal toxicities (39). \\
\hline & 188 & 64-73.6 & $81 \%(5 \mathrm{yr})$ & $77 \%(5 \mathrm{yr})$ & Toxicity occurs in individual patients. Effective and safe (40). \\
\hline & 75 & $57.6-73.6$ & $57 \%(5 \mathrm{yr})$ & $55 \%(5 \mathrm{yr})$ & Toxicity occurs in individual patients. Effective and safe (41). \\
\hline \multirow[t]{2}{*}{ Head and Neck } & 236 & $57.6-64.0$ & $\begin{array}{l}35-68 \% \\
(5 \mathrm{yr})\end{array}$ & $24-75 \%$ (5 yr) & $\begin{array}{l}\text { Promising outcomes with reduced acute and late reactions. } \\
\text { Effective and safe (42). }\end{array}$ \\
\hline & 53 & 24 & $78 \%$ (3 yr) & $82 \%$ (3 yr) & $\begin{array}{l}\text { Acceptable toxicity. Treatment was tolerated, with moderate acute and late toxicity } \\
\text { (43). }\end{array}$ \\
\hline \multirow[t]{6}{*}{$\begin{array}{l}\text { Adenoid cystic } \\
\text { carcinomas }\end{array}$} & 18 & $57.6-67.4$ & $72 \%(5 \mathrm{yr})$ & $92 \%(5 \mathrm{yr})$ & $\begin{array}{l}\text { Regarding late reactions, } 2 \text { patients developed grade } 3 \text { mandible } \\
\text { osteoradionecrosis, and } 1 \text { had grade } 3 \text { hemorrhage of the tongue base. Effective } \\
\text { and safe (44). }\end{array}$ \\
\hline & 309 & 23.9 & $\begin{array}{c}88.9 \% \\
(3 y r)\end{array}$ & 83.7\%(3 yr) & $\begin{array}{l}\text { only } 4 \% \text { of patients developed grade III dysphagia and late toxicities of grade } 3 \text { or } \\
\text { higher occurred in only3 patients (45). }\end{array}$ \\
\hline & & & $\begin{array}{c}74.6 \% \\
(5 \mathrm{yr})\end{array}$ & $58.5 \%(5 y r)$ & \\
\hline & 289 & $55.2-70.4$ & $94 \%(2 \mathrm{yr})$ & $88 \%(2 \mathrm{yr})$ & $\begin{array}{l}15 \% \text { of the patients experienced late toxicities that were scored as grade } 3 \text { or } \\
\text { higher, with osteonecrosis }\end{array}$ \\
\hline & & & $74 \%$ (5 yr) & $68 \%(5 y r)$ & being the most common (46). \\
\hline & 58 & 18 & $\begin{array}{l}76.5 \%(5 \\
y r)\end{array}$ & $59.6 \%(5 \mathrm{yr})$ & $\begin{array}{l}\text { C12 therapy resulted in superior LC, PFS, and OS without a significant difference } \\
\text { between patients with inoperable and partially resected ACC (47). }\end{array}$ \\
\hline Mucosal melanomas & 18 & 74 & $\begin{array}{c}16.2 \%(3 \\
y r)\end{array}$ & $58.3(3 \mathrm{yr})$ & $\begin{array}{l}\text { Grade III or higher late toxicity was not observed. CIRT has shown good local } \\
\text { control in mucosal melanomas but long-term survival is still poor (48). }\end{array}$ \\
\hline \multirow[t]{2}{*}{ Choroidal melanoma } & 116 & $60-85$ & $\begin{array}{l}80.4 \%(5 \\
y r)\end{array}$ & $92.8 \%(5 \mathrm{yr})$ & $\begin{array}{l}\text { The long term outcomes of CIRT for choroidal melanoma with excellent local } \\
\text { control and eye retention rates (49). }\end{array}$ \\
\hline & 79 & 60 & $\begin{array}{l}98 \%(5 \mathrm{yr}) \\
79 \%(10 \\
\mathrm{yr})\end{array}$ & $\begin{array}{l}89 \%(5 \mathrm{yr}) \\
88 \%(10 \mathrm{yr})\end{array}$ & $\begin{array}{l}\text { Acute and late toxicities were mild. With no grade }>3 \text { reactions. Safe and effective } \\
\text { (50). }\end{array}$ \\
\hline Chordomas & 96 & 60 & $\begin{array}{l}88 \%(5 \mathrm{yr}) \\
75 \%(10 \\
\mathrm{yr})\end{array}$ & $\begin{array}{l}70 \%(5 \mathrm{yr}) \\
54 \%(10 \mathrm{yr})\end{array}$ & $\begin{array}{l}\text { Acute and late toxicities were mild. With no grade }>3 \text { reactions. Safe and effective } \\
\text { (51). }\end{array}$ \\
\hline \multirow[t]{5}{*}{ Skull base chordoma } & 155 & $60-74$ & $\begin{array}{c}95 \%(3 \mathrm{yr}) \\
85 \%(5 \mathrm{yr}) \\
75 \%(10 \\
y r)\end{array}$ & $\begin{array}{l}82 \%(3 \mathrm{yr}) \\
72 \%(5 \mathrm{yr}) \\
54 \%(10 \mathrm{yr})\end{array}$ & safe and effective (52). \\
\hline & 33 & $48-60.8$ & $\begin{array}{c}87.7 \%(5 \\
y r) \\
67 \%(10 \\
y r)\end{array}$ & $\begin{array}{l}85.1 \%(5 \mathrm{yr}) \\
63.8 \%(10 \mathrm{yr})\end{array}$ & $\begin{array}{l}\text { Normal tissues showed a mild reaction without any severe morbidity of important } \\
\text { organs (53). }\end{array}$ \\
\hline & 23 & 70.4 & $83 \%(3 \mathrm{yr})$ & $94 \%(3 \mathrm{yr})$ & Toxicity ( $\geq$ grade 3) late were observed in nine patients. Useful and safe (54). \\
\hline & 188 & $64-73.6$ & $\begin{array}{l}81.1 \%(5 \\
y r)\end{array}$ & $77.2 \%(5 \mathrm{yr})$ & Toxicity occurs in individual patients. Effective and safe (40). \\
\hline & 56 & $60-74$ & $\begin{array}{c}100 \%(2 \\
y r)\end{array}$ & $\begin{array}{l}76 \%(2 \mathrm{yr}) \\
53 \%(3 \mathrm{yr})\end{array}$ & No higher toxicity occurred within the follow-up time. Effective and safe (55). \\
\hline \multirow[t]{2}{*}{$\begin{array}{l}\text { skull base } \\
\text { chondrosarcomas }\end{array}$} & 101 & 60 & $\begin{array}{c}100 \%(1 \\
y r)\end{array}$ & $98.6 \%(1 \mathrm{yr})$ & $\begin{array}{l}\text { No toxicity worse than Common Toxicity Criteria grade } 3 \text { was observed after } \\
\text { treatment (56). }\end{array}$ \\
\hline & & & $\begin{array}{c}98.5 \%(2 \\
y r) \\
92.9 \%(4 \\
y r)\end{array}$ & $\begin{array}{l}97.2 \%(2 \mathrm{yr}) \\
90.5 \%(4 \mathrm{yr})\end{array}$ & \\
\hline Skull Base Sarcomas & 53 & $54-73.5$ & $\begin{array}{c}91.2 \%(1 \\
y r) \\
80.2 \%(2 \\
y r)\end{array}$ & $\begin{array}{l}\text { LRFS: } 89.2 \%(1 \mathrm{yr}) \\
\qquad 80.2 \%(2 \mathrm{yr})\end{array}$ & With few observed acute and late toxicities. Safe and effective (57). \\
\hline
\end{tabular}


TABLE 4 | Continued

\begin{tabular}{|c|c|c|c|c|c|}
\hline Cancer & $\begin{array}{l}\text { Patient } \\
\text { number }\end{array}$ & $\begin{array}{l}\text { Target } \\
\text { dose, } \\
\text { GyE }\end{array}$ & $\begin{array}{l}\text { Overall } \\
\text { survival }\end{array}$ & Local control & Late toxicity at reporting and results \\
\hline \multirow[t]{2}{*}{ meningioma } & 42 & $36-60$ & $\begin{array}{l}89.6 \%(1 \\
y r)\end{array}$ & $71 \%(1 \mathrm{yr})$ & Safe and effective (58). \\
\hline & & & $\begin{array}{c}71.4 \%(2 \\
y r)\end{array}$ & $56.5 \%(2 \mathrm{yr})$ & \\
\hline \multirow[t]{4}{*}{ Prostate Cancers } & 175 & 66 & / & / & No grade $\geq 3$ toxicities (59). \\
\hline & 46 & $51.6-57.6$ & / & / & $\begin{array}{l}\text { No other G2 acute toxicities were observed. The new shortened CIRT schedule } \\
\text { over } 3 \text { weeks was considered as feasible (60). }\end{array}$ \\
\hline & 664 & 57.6 & $\begin{array}{l}95.2 \%(5 \\
y r)\end{array}$ & / & $\begin{array}{l}\text { Advancement in hypofractionation could be safely achieved with C-ion RT for } \\
\text { prostate cancer (61). }\end{array}$ \\
\hline & 2157 & $51.76-66$ & $\begin{array}{c}96-100(5 \\
y r)\end{array}$ & $96-99 \%$ (5 yr) & $\begin{array}{l}\text { No grade } \geq 3 \text { toxicities. Favorable overall outcomes of CIRT for prostate cancer } \\
\text { (62). }\end{array}$ \\
\hline LACC & 22 & $64-72$ & $50 \%(5 \mathrm{yr})$ & $68.2 \%(5 y r)$ & $\begin{array}{l}\text { No grade } 2 \text { toxicities. CIRT has the potential to improve the treatment for locally } \\
\text { YOUYIJIANadvanced bulky cervical cancer (63). }\end{array}$ \\
\hline \multirow[t]{10}{*}{$\mathrm{HCC}$} & 64 & 52.8 & $22(5 \mathrm{yr})$ & $88(5 \mathrm{yr})$ & Excellent local control was obtained independent of tumor location (64). \\
\hline & $76 / 58$ & 55.2 & $48 \%(2 \mathrm{yr})$ & $83 \%(2 \mathrm{yr})$ & Safe and effective (65). \\
\hline & 24 & 49.5-79.5 & $92 \%(1 \mathrm{yr})$ & $92 \%(1 \mathrm{yr})$ & Safe and effective (66). \\
\hline & & & $50 \%(3 \mathrm{yr})$ & $81 \%(3 \mathrm{yr})$ & \\
\hline & & & $25 \%(5 \mathrm{yr})$ & $81 \%(5 \mathrm{yr})$ & \\
\hline & 126 & $48-54$ & $90 \%(1 \mathrm{yr})$ & $95 \%(1 \mathrm{yr})$ & Safe and effective (67). \\
\hline & & & $50 \%(3 \mathrm{yr})$ & $91 \%(3 \mathrm{yr})$ & \\
\hline & & & 25 (5 yr) & $90(5 \mathrm{yr})$ & \\
\hline & 101 & $52.8-76$ & $36 \%(5 \mathrm{yr})$ & $93 \%$ (5 yr) & Safe and effective (68). \\
\hline & 31 & $52.8-60$ & $82 \%(2 \mathrm{yr})$ & $89 \%(2 y r)$ & $\begin{array}{l}\text { C-ion RT was effective with minimal toxicities for } 80 \text { years or older patients with } \\
\text { hepatocellular carcinoma (69). }\end{array}$ \\
\hline \multirow[t]{4}{*}{ Pancreatic Cancers } & 26 & $30-36.8$ & $42 \%(5 y r)$ & $\begin{array}{l}\text { None of the patients } \\
\text { experienced local } \\
\text { failure. }\end{array}$ & Safe and effective (70). \\
\hline & 64 & 55.2 & $\begin{array}{l}84 \%(1 \mathrm{yr}) \\
53 \%(2 \mathrm{yr})\end{array}$ & $82 \%(2 \mathrm{yr})$ & No grade $\geq 3$ toxicities (71). \\
\hline & 72 & $52.8-55.2$ & $\begin{array}{l}73 \%(1 \mathrm{yr}) \\
46 \%(2 \mathrm{yr})\end{array}$ & / & No patients developed late grade 4 or 5 toxicity (72). \\
\hline & 72 & $\begin{array}{c}43.2- \\
55.2\end{array}$ & $\begin{array}{l}73 \%(1 \mathrm{yr}) \\
48 \%(2 \mathrm{yr})\end{array}$ & / & $\begin{array}{l}\text { Carbon ion RT with concurrent full-dose gemcitabine was well tolerated and } \\
\text { effective in patients with unresectable locally advanced pancreatic cancer (65). }\end{array}$ \\
\hline $\begin{array}{l}\text { Recurrent and } \\
\text { Previously Irradiated } \\
\text { Cancers }\end{array}$ & 52 & $67-182$ & / & $70.3 \%(1.2 \mathrm{yr})$ & $\begin{array}{l}\text { Without grade }>2 \text { toxicity. Further dose escalation should be viewed with caution } \\
\text { (73). }\end{array}$ \\
\hline $\begin{array}{l}\text { Recurrent Rectal } \\
\text { Cancer }\end{array}$ & 180 & 73.6 & $59 \%(5 \mathrm{yr})$ & $88 \%(5 \mathrm{yr})$ & Without grade $>3$ toxicities. Safe and effective (74). \\
\hline sinonasal malignancies & 911 & $18-24$ & $\begin{array}{l}75.1 \%(3 \\
y r)\end{array}$ & $80.2 \%(3 \mathrm{yr})$ & Safe and effective (75). \\
\hline \multirow[t]{2}{*}{ Breast Cancer } & 7 & $48-60$ & \multirow{2}{*}{\multicolumn{2}{|c|}{$\begin{array}{l}\text { All cases were alive without } \\
\text { recurrence ( } 5 \text { yr) } \\
\text { Surviving more than } 8 \text { years without } \\
\text { local recurrence. }\end{array}$}} & $\begin{array}{l}\text { At the end of } 2017 \text {, all cases were alive without recurrence or late had not caused } \\
\text { any late adverse reaction. Safe and effective (76). }\end{array}$ \\
\hline & 1 & 36 & & & Safe and effective (77). \\
\hline
\end{tabular}

Recurrent NPC, Recurrent nasopharyngeal carcinoma; STS, Osteosarcomas and Soft Tissue Sarcomas; HCC, Hepatocellular Carcinomas; LACC, Locally Advanced Cervical Cancer; LRFS, Local Relapse Free Survival; RRFS, Regional Relapse Free Survival.

providing a therapeutic strategy that combines GTe-RGDenhanced RT with checkpoint blockade immunotherapy to effectively and systematically eliminate tumors, providing an attractive clinical alternative to oncology therapy (100). Duo designed a radiosensitizer of ultra-thin antimonene nanoparticles (AMNPs) that could achieve effective radiochemotherapy effects by inducing a strong oxidative stress response and their significant high radiotoxicity. This technique could expand the application range of antimonene as an effective radiosensitizer, and promoted its modulated and effective radiosensitizer effect in clinic (101).
Gadolinium-based nanoparticles (GdNPs), which process high relaxation time and high atomic number $(Z=64)$, have attracted substantial attention. GdNPs have high electron density. GdNPs have high electron density. Therefore, ionizing radiation contains notes nanoparticles aqueous solution, in addition to the interaction between ionizing radiation and water can cause water molecules ionization and secondary electron emission, the incident particles and secondary electron interaction with $\mathrm{Gd}$ will also lead to request for nanoparticles electron emission increases around a few nanometer scale, electronic further solution of released from water molecules 
lead to the water oxide increased ROS. The measurement of hydroxyl radicals, which play a major role in ROS, can directly reflect the sensitization effect of Gd on ionizing radiation. It is worth mentioning that GdNPs which as a T1-enhanced clinical magnetic resonance imaging material, can provide highresolution clear imaging of soft tissues. GdNPs can be used as sensitizing materials for ionizing radiation, enhancing both $\mathrm{X}$ ray and particle beam irradiation (102). Ultra-small gadolinium oxide nanocrystals (GONs) are attractive gadolinium nanocrystals, which have a high density of gadolinium/contrast agent units. GONs have been developed as advanced T1weighted MRI contrast agents due to their high longitudinal relaxivities and small $\mathrm{r} 2 / \mathrm{r} 1$ ratios. MA found that GONs have good biocompatibility in breast cancer McF-7 cells (103). Amirrashedi et al. first studied the radio sensitizing agent properties of GONs in a gel-filled volume model, where the maximum dose enhancement range of GONs was $15 \%-24 \%$ (104). Some scholars found that under photon and proton irradiation, the enhancement of ROS produced by GONs was dose-dependent, and the factor was 1.94 compared with radiation control alone. Core-inner-valence ionization of atoms could de-excite electrons by means of a powerful Gd-Gd interatomic de-excitation process. The radiosensitizing biomechanism of GONs under X-ray remains unclear. Shady Kotb et al. reported a kind of Gd-based nanoparticles AGuIX, which is composed of a polysiloxane core and its surrounding covalently attached gadolinium chelate network and with a hydrodynamic diameter of less than $5 \mathrm{~nm}$. They concluded that AGuIX is an effective T1-MRI contrast agent, and that the combination of AGuIX and radiation not only significantly enhanced the dose in vitro, but also improved survival in mice with aggressive brain tumors, demonstrating the safety and efficacy of AGuIX as a potential clinical contrast agent and radiosensitizer (102).

Among all kinds of nanomaterials applied in radiotherapy, gold nanoparticles (GNP) has been considered as a potential tool for diagnosis and treatment of various cancers due to its small particle size, good dispersion, strong stability and good biocompatibility $(105,106)$. So GNPs have long been considered as a potential tool for the diagnosis and treatment of many types of cancer. GNPs are the first metal nanoparticles used in radiation sensitization research and they are also the most studied nanoparticles at present, and the enhancement effects of which have been demonstrated both in vitro and in vivo $(84,94)$. In addition, some researchers have also reported some other sensitizers, such as silver nanoparticles (107), titanium oxide (108), bismuth oxide (109), etc.

\section{CIRT Sensitizing Agent}

Although the materials mentioned above can be used as sensitizing agent for XRT and PT (110), few of them can be used as sensitizing agent for carbon ion therapy. Kaur found that the presence of glucose-capped gold nanoparticles in HeLa cells led to an enhancement of $41 \%$ in the RBE value of carbon ion irradiation (111). It has been reported that nano gold can significantly affect carbon ion irradiation, and this effect is obviously dependent on the concentration of nano gold.
Porcel's team found that Pt nanoparticles can significantly enhance DSB damage induced by carbon ion irradiation (112). What's more, in another study, he found that gadolinium based nanoparticles (GBNPs) can enhance the sensitivity of Chinese hamster ovary cells to $\mathrm{C}^{6+}$ and $\mathrm{He}^{2+}$ radiation (113). In addition, AGuIX could significantly enhance the killing effect of carbon ions on head and neck anti-radiation tumor cells (83). In carbon ion therapy, more efforts are needed to expand the uses of metal nanoparticles and explore their biological mechanisms, especially for therapeutic agents such as gadolinium. Some researchers have studied the radiation sensitization effect of theranostic metal-based nanoparticles in carbon ion irradiation and its mechanism (94). Li found that pretreatment with GONs led to the enhancement of hydroxyl radical and ROS production, which contributes to cell cycle arrest at G2/M phase to allow for repair of damaged DNA with DSBs. They thought that based on the good biocompatibility, the instinctive advantage of Gd as an MRI contrast agent, and the sensitization effect stated above, GONs may be a potential theranostic sensitizer in NSCLC patients under carbon ion radiotherapy after further in vivo preclinical studies (114).

\section{PROSPECTS AND CONCLUDING REMARKS}

With the aggravation of the aging of the global population and the acceleration of industrialization and urbanization, malignant tumors continue to grow globally and bring enormous physical, emotional and economic pressure to individuals, families, communities and health systems. It has become one of the major problems that seriously threaten human health. There is no doubt that the emergence of CIRT has brought good news to human health, especially for those recurrent cancer, antiradiation cancer. In the case that increasing the radiation dose still fails to achieve good results, the emergence of CIRT undoubtedly provides a new opportunity. Not only are carbon ions able to kill tumor cells with greater precision, they also retain the most of healthy tissue. Another potential benefit of CIRT may be in combination with immunotherapy. CIRT with high LET radiation has been shown to have higher immunogenicity in radiation-induced cell death and therefore has a significant advantage in combination immunotherapy (115). The existing clinical pre-studies and on-the-spot studies have achieved remarkable success. But this new processing technology also inevitably brings some problems and troubles.

First of all, basic biological research of CIRT needs to be further explored. From the analysis of clinical data, there is no doubt about the effectiveness of CIRT for cancer, especially in the treatment of some recurrent cancer has been a great success. However, due to the high investment and related uncertainties in the aspects of carbocation dose transfer and radiobiological effects, it is unlikely to replace traditional radiotherapy as the mainstream treatment in the short term. The clinical trials related to CIRT need to be further strengthened, and more prospective trials are needed to clarify the role of 
CIRT in clinical practice. Secondly, the miniaturization of the CIRT device. The technology of CIRT is advanced, however the processing and operation of CIRT equipment requires high precision, large volume of equipment, and high requirements for the research technology of the accelerator. The miniaturization of the accelerator is still an important issue at present. Thirdly, the dynamic monitoring of tumor movement in radiotherapy is still an urgent problem to be solved at present to improve the effect of radiotherapy. Dynamically monitor tumor motion during RT mainly includes two parts: tumor detection and tracking model establishment. CIRT uses CT simulation to personalize the radiotherapy plan for the patient. CT simulation location is a virtual simulation process of target determination and planning based on CT images and other medical images, which is a kind of three-dimensional image simulation. After the completion of the CT, the physical and dosimetric experts will set the radiotherapy dose according to the scope outlined by the clinical experts, and design and complete the radiotherapy plan. So there is still some margin of error in the range that this calculation outlines. As for the establishment of tracking model, it involves many links of tumor signal acquisition, measurement, calculation, transmission, control and treatment. Therefore, it is difficult for CIRT to dynamically monitor tumor movement at present. In addition, compared with X-ray treatment, CIRT related sensitizers are still in the minority. The extreme sensitivity of the carbon ion beam leads to the uncertainty of the range of the carbon ion beam, which provides a new choice for the treatment of tumors and to a certain extent enhances the killing degree of tumor cells. However, due to the scarcity of carbon ion research and the lack of specific biological mechanism, the corresponding sensitizer is still in the preliminary stage of exploration. At present, only gadolinium-based, gold-based and other nanomaterials are known. The clinical application of carbon sensitizers remains challenging. Most notably, the construction cost of carbon ion treatment equipment and treatment cost need to be reduced. The investment cost of carbon ion therapy center is huge, and the late maintenance cost is also very expensive. With the high treatment cost borne by patients, the advantages of CIRT are greatly reduced in the face of further promotion and

\section{REFERENCES}

1. Bray F, Ferlay J, Soerjomataram I, Siegel RL, Torre LA, Jemal A. Global Cancer Statistics 2018: GLOBOCAN Estimates of Incidence and Mortality Worldwide for 36 Cancers in 185 Countries. Ca-Cancer J Clin (2018) 68 (6):394-424. doi: 10.3322/caac.21492

2. Feng R-M, Zong Y-N, Cao S-M, Xu R-H. Current Cancer Situation in China: Good or Bad News From the 2018 Global Cancer Statistics? Cancer Commun (2019) 39(1):22. doi: 10.1186/s40880-019-0368-6

3. Siegel RL, Miller KD, Jemal A. Cancer Statistics, 2020. Ca-Cancer J Clin (2020) 70(1):7-30. doi: 10.3322/caac. 21590

4. Sung H, Ferlay J, Siegel RL, Laversanne M, Soerjomataram I, Jemal A, et al. Global Cancer Statistics 2020: GLOBOCAN Estimates of Incidence and Mortality Worldwide for 36 Cancers in 185 Countries. CA: A Cancer J Clin (2021) 71(3):209-49. doi: 10.3322/caac.21660

5. Rackwitz T, Debus J. Clinical Applications of Proton and Carbon Ion Therapy. Semin Oncol (2019) 46(3):226-32. doi: 10.1053/j.seminoncol. 2019.07.005 application. Therefore, reducing the cost of CIRT is still an important issue for people.

At present, more and more carbon ion centers are being prepared for construction around the world, prospective clinical trials on the treatment of various types of cancers are also being carried out gradually, and the technology of CIRT has become increasingly mature. Objective evaluation of the real advantages of CIRT, clear the value and limitations of carbon ion application, the use of existing conditions to do the basic data and basic technical research work, make full technical reserve, accumulate rich clinical experience. We believe that in the near future, with the progress of science and technology and the indepth research, whether it is the reduction of equipment cost, treatment cost reduction, or the further conquest of cancer, the future will be gradually solved. The data of CIRT will be gradually improved, so that its characteristics and advantages can be more clearly understood, so as to provide more and more effective treatment options for cancer patients.

\section{DATA AVAILABILITY STATEMENT}

The raw data supporting the conclusions of this article will be made available by the authors, without undue reservation.

\section{AUTHOR CONTRIBUTIONS}

XW conducted the literature review and drafted the manuscript. TG, WL, and XT contributed to review and edited and formatted the final manuscript. XC, GL, and XH edited and contributed to the revised manuscript. All authors contributed to the article and approved the submitted version.

\section{FUNDING}

The authors acknowledge funding from National Key R\&D Program of China (2020YFC2007301, 2020YFC2007300).

6. Mohamad O, Sishc BJ, Saha J, Pompos A, Rahimi A, Story MD, et al. Carbon Ion Radiotherapy: A Review of Clinical Experiences and Preclinical Research, With an Emphasis on DNA Damage/Repair. Cancers (2017) 9 (6):66. doi: 10.3390/cancers9060066

7. Pompos A, Durante M, Choy H. Heavy Ions in Cancer Therapy. JAMA Oncol (2016) 2(12):1539-40. doi: 10.1001/jamaoncol.2016.2646

8. Traini G, Mattei I, Battistoni G, Bisogni MG, De Simoni M, Dong Y, et al. Review and Performance of the Dose Profiler, a Particle Therapy Treatments Online Monitor. Phys Med (2019) 65:84-93. doi: 10.1016/j.ejmp.2019.07.010

9. Lazar AA, Schulte R, Faddegon B, Blakely EA, Roach M3rd. Clinical Trials Involving Carbon-Ion Radiation Therapy and the Path Forward. Cancer (2018) 124(23):4467-76. doi: 10.1002/cncr.31662

10. Jeong J, Taasti VT, Jackson A, Deasy JO. The Relative Biological Effectiveness of Carbon Ion Radiation Therapy for Early Stage Lung Cancer. Radiother Oncol (2020) 153:265-71. doi: 10.1016/j.radonc.2020.09.027

11. Mohamad O, Yamada S, Durante M. Clinical Indications for Carbon Ion Radiotherapy. Clin Oncol (R Coll Radiol) (2018) 30(5):317-29. doi: 10.1016/ j.clon.2018.01.006 
12. Allen C, Borak TB, Tsujii H, Nickoloff JA. Heavy Charged Particle Radiobiology: Using Enhanced Biological Effectiveness and Improved Beam Focusing to Advance Cancer Therapy. Mutat Res (2011) 711(12):150-7. doi: 10.1016/j.mrfmmm.2011.02.012

13. Lomax AJ. Charged Particle Therapy: The Physics of Interaction. Cancer J (2009) 15(4):285-91. doi: 10.1097/PPO.0b013e3181af5cc7

14. Paganetti H. Relative Biological Effectiveness (RBE) Values for Proton Beam Therapy. Variations as a Function of Biological Endpoint, Dose, and Linear Energy Transfer. Phys Med Biol (2014) 59(22):R419-72. doi: 10.1088/00319155/59/22/R419

15. Fossati P, Matsufuji N, Kamada T, Karger CP. Radiobiological Issues in Prospective Carbon Ion Therapy Trials. Med Phys (2018) 45(11):e1096-110. doi: $10.1002 / \mathrm{mp} .12506$

16. Habermehl D, Ilicic K, Dehne S, Rieken S, Orschiedt L, Brons S, et al. The Relative Biological Effectiveness for Carbon and Oxygen Ion Beams Using the Raster-Scanning Technique in Hepatocellular Carcinoma Cell Lines. PloS One (2014) 9(12):e113591. doi: 10.1371/journal.pone.0113591

17. Ohno T. Particle Radiotherapy With Carbon Ion Beams. Epma J (2013) 4 (1):9. doi: 10.1186/1878-5085-4-9

18. Friedrich T, Scholz U, Elsässer T, Durante M, Scholz M. Systematic Analysis of RBE and Related Quantities Using a Database of Cell Survival Experiments With Ion Beam Irradiation. J Radiat Res (2013) 54(3):494514. doi: $10.1093 / \mathrm{jrr} / \mathrm{rrs} 114$

19. Mohan R, Grosshans D. Proton Therapy - Present and Future. Adv Drug Deliv Rev (2017) 109:26-44. doi: 10.1016/j.addr.2016.11.006

20. Tinganelli W, Ma NY, Von Neubeck C, Maier A, Schicker C, KraftWeyrather W, et al. Influence of Acute Hypoxia and Radiation Quality on Cell Survival. J Radiat Res (2013) 54 Suppl 1(Suppl 1):i23-30. doi: 10.1093/ jrr/rrt065

21. Kobayashi D, Oike T, Shibata A, Niimi A, Kubota Y, Sakai M, et al. Mitotic Catastrophe is a Putative Mechanism Underlying the Weak Correlation Between Sensitivity to Carbon Ions and Cisplatin. Sci Rep (2017) 7:40588. doi: $10.1038 /$ srep 40588

22. Yu Z, Hartel C, Pignalosa D, Kraft-Weyrather W, Jiang GL, Diaz-Carballo D, et al. The Effect of X-Ray and Heavy Ions Radiations on Chemotherapy Refractory Tumor Cells. Front Oncol (2016) 6:64. doi: 10.3389/fonc.2016.00064

23. Loeffler JS, Durante M. Charged Particle Therapy-Optimization, Challenges and Future Directions. Nat Rev Clin Oncol (2013) 10(7):411-24. doi: 10.1038/nrclinonc.2013.79

24. Oike T, Niimi A, Okonogi N, Murata K, Matsumura A, Noda SE, et al. Visualization of Complex DNA Double-Strand Breaks in a Tumor Treated With Carbon Ion Radiotherapy. Sci Rep (2016) 6:22275. doi: 10.1038/ srep22275

25. Suetens A, Moreels M, Quintens R, Chiriotti S, Tabury K, Michaux A, et al. Carbon Ion Irradiation of the Human Prostate Cancer Cell Line PC3: A Whole Genome Microarray Study. Int J Oncol (2014) 44(4):1056-72. doi: 10.3892/ijo.2014.2287

26. Chiblak S, Tang Z, Campos B, Gal Z, Unterberg A, Debus J, et al. Radiosensitivity of Patient-Derived Glioma Stem Cell 3-Dimensional Cultures to Photon, Proton, and Carbon Irradiation. Int J Radiat Oncol Biol Phys (2016) 95(1):112-9. doi: 10.1016/j.ijrobp.2015.06.015

27. Mohamad O, Tabuchi T, Nitta Y, Nomoto A, Sato A, Kasuya G, et al. Risk of Subsequent Primary Cancers After Carbon Ion Radiotherapy, Photon Radiotherapy, or Surgery for Localised Prostate Cancer: A Propensity Score-Weighted, Retrospective, Cohort Study. Lancet Oncol (2019) 20 (5):674-85. doi: 10.1016/S1470-2045(18)30931-8

28. Kamada T, Tsujii H, Blakely EA, Debus J, De Neve W, Durante M, et al. Carbon Ion Radiotherapy in Japan: An Assessment of 20 Years of Clinical Experience. Lancet Oncol (2015) 16(2):e93-e100. doi: 10.1016/S1470-2045 (14)70412-7

29. Romesser PB, Cahlon O, Scher ED, Hug EB, Sine K, DeSelm C, et al. Proton Beam Reirradiation for Recurrent Head and Neck Cancer: MultiInstitutional Report on Feasibility and Early Outcomes. Int J Radiat Oncol Biol Phys (2016) 95(1):386-95. doi: 10.1016/j.ijrobp.2016.02.036

30. McDonald MW, Zolali-Meybodi O, Lehnert SJ, Estabrook NC, Liu Y, Cohen-Gadol AA, et al. Reirradiation of Recurrent and Second Primary Head and Neck Cancer With Proton Therapy. Int J Radiat Oncol Biol Phys (2016) 96(4):808-19. doi: 10.1016/j.ijrobp.2016.07.037
31. Yang Z, Li H, Li Y, Li Y, Chang Y, Li Q, et al. Statistical Evaluation of WorstCase Robust Optimization Intensity-Modulated Proton Therapy Plans Using an Exhaustive Sampling Approach. Radiat Oncol (2019) 14(1):129. doi: 10.1186/s13014-019-1335-8

32. Laine AM, Pompos A, Timmerman R, Jiang S, Story MD, Pistenmaa D, et al. The Role of Hypofractionated Radiation Therapy With Photons, Protons, and Heavy Ions for Treating Extracranial Lesions. Front Oncol (2015) 5:302. doi: $10.3389 /$ fonc.2015.00302

33. Story M, Pompos A, Timmerman R. On the Value of Carbon-Ion Therapy. Phys Today (2016) 69(11):14-6. doi: 10.1063/PT.3.3348

34. Hu J, Bao C, Gao J, Guan X, Hu W, Yang J, et al. Salvage Treatment Using Carbon Ion Radiation in Patients With Locoregionally Recurrent Nasopharyngeal Carcinoma: Initial Results. Cancer (2018) 124(11):242737. doi: $10.1002 /$ cncr.31318

35. Kamada T, Tsujii H, Tsuji H, Yanagi T, Mizoe JE, Miyamoto T, et al. Efficacy and Safety of Carbon Ion Radiotherapy in Bone and Soft Tissue Sarcomas. J Clin Oncol (2002) 20(22):4466-71. doi: 10.1200/JCO.2002.10.050

36. Serizawa I, Kagei K, Kamada T, Imai R, Sugahara S, Okada T, et al. Carbon Ion Radiotherapy for Unresectable Retroperitoneal Sarcomas. Int J Radiat Oncol Biol Phys (2009) 75(4):1105-10. doi: 10.1016/j.ijrobp.2008.12.019

37. Matsunobu A, Imai R, Kamada T, Imaizumi $T$, Tsuji $H$, Tsujii $H$, et al. Impact of Carbon Ion Radiotherapy for Unresectable Osteosarcoma of the Trunk. Cancer (2012) 118(18):4555-63. doi: 10.1002/cncr.27451

38. Sugahara S, Kamada T, Imai R, Tsuji H, Kameda N, Okada T, et al. Carbon Ion Radiotherapy for Localized Primary Sarcoma of the Extremities: Results of a Phase I/II Trial. Radiother Oncol (2012) 105(2):226-31. doi: 10.1016/ j.radonc.2012.09.010

39. Matsumoto K, Imai R, Kamada T, Maruyama K, Tsuji H, Tsujii H, et al. Impact of Carbon Ion Radiotherapy for Primary Spinal Sarcoma. Cancer (2013) 119(19):3496-503. doi: 10.1002/cncr.28177

40. Imai R, Kamada T, Araki N. Carbon Ion Radiation Therapy for Unresectable Sacral Chordoma: An Analysis of 188 Cases. Int J Radiat Oncol Biol Phys (2016) 95(1):322-7. doi: 10.1016/j.ijrobp.2016.02.012

41. Maruyama K, Imai R, Kamada T, Tsuji H, Tsujii H. Carbon Ion Radiation Therapy for Chondrosarcoma. Int J Radiat Oncol Biol Phys (2012) 84:S139. doi: 10.1016/j.ijrobp.2012.07.159

42. Mizoe JE, Hasegawa A, Jingu K, Takagi R, Bessyo H, Morikawa T, et al. Results of Carbon Ion Radiotherapy for Head and Neck Cancer. Radiother Oncol (2012) 103(1):32-7. doi: 10.1016/j.radonc.2011.12.013

43. Jensen AD, Nikoghosyan AV, Lossner K, Haberer T, Jäkel O, Münter MW, et al. COSMIC: A Regimen of Intensity Modulated Radiation Therapy Plus Dose-Escalated, Raster-Scanned Carbon Ion Boost for Malignant Salivary Gland Tumors: Results of the Prospective Phase 2 Trial. Int J Radiat Oncol Biol Phys (2015) 93(1):37-46. doi: 10.1016/j.ijrobp.2015.05.013

44. Koto M, Hasegawa A, Takagi R, Ikawa H, Naganawa K, Mizoe JE, et al. Evaluation of the Safety and Efficacy of Carbon Ion Radiotherapy for Locally Advanced Adenoid Cystic Carcinoma of the Tongue Base. Head Neck (2016) 38 Suppl 1:E2122-6. doi: 10.1002/hed.24397

45. Jensen AD, Poulakis M, Nikoghosyan AV, Welzel T, Uhl M, Federspil PA, et al. High-LET Radiotherapy for Adenoid Cystic Carcinoma of the Head and Neck: 15 Years' Experience With Raster-Scanned Carbon Ion Therapy. Radiother Oncol (2016) 118(2):272-80. doi: 10.1016/j.radonc.2015.05.010

46. Sulaiman NS, Demizu Y, Koto M, Saitoh JI, Suefuji H, Tsuji H, et al. Multicenter Study of Carbon-Ion Radiation Therapy for Adenoid Cystic Carcinoma of the Head and Neck: Subanalysis of the Japan Carbon-Ion Radiation Oncology Study Group (J-CROS) Study (1402 HN). Int J Radiat Oncol Biol Phys (2018) 100(3):639-46. doi: 10.1016/j.ijrobp.2017.11.010

47. Jensen AD, Nikoghosyan AV, Poulakis M, Höss A, Haberer T, Jäkel O, et al. Combined Intensity-Modulated Radiotherapy Plus Raster-Scanned Carbon Ion Boost for Advanced Adenoid Cystic Carcinoma of the Head and Neck Results in Superior Locoregional Control and Overall Survival. Cancer (2015) 121(17):3001-9. doi: 10.1002/cncr.29443

48. Mohr A, Chaudhri N, Hassel JC, Federspil PA, Vanoni V, Debus J, et al Raster-Scanned Intensity-Controlled Carbon Ion Therapy for Mucosal Melanoma of the Paranasal Sinus. Head Neck (2016) 38 Suppl 1:E144551. doi: 10.1002/hed.24256

49. Toyama S, Tsuji H, Mizoguchi N, Nomiya T, Kamada T, Tokumaru S, et al Long-Term Results of Carbon Ion Radiation Therapy for Locally Advanced 
or Unfavorably Located Choroidal Melanoma: Usefulness of CT-Based 2Port Orthogonal Therapy for Reducing the Incidence of Neovascular Glaucoma. Int J Radiat Oncol Biol Phys (2013) 86(2):270-6. doi: 10.1016/ j.ijrobp.2012.12.022

50. Uhl M, Mattke M, Welzel T, Oelmann J, Habl G, Jensen AD, et al. High Control Rate in Patients With Chondrosarcoma of the Skull Base After Carbon Ion Therapy: First Report of Long-Term Results. Cancer (2014) 120 (10):1579-85. doi: 10.1002/cncr.28606

51. Schulz-Ertner D, Karger CP, Feuerhake A, Nikoghosyan A, Combs SE, Jäkel O, et al. Effectiveness of Carbon Ion Radiotherapy in the Treatment of SkullBase Chordomas. Int J Radiat Oncol Biol Phys (2007) 68(2):449-57. doi: 10.1016/j.ijrobp.2006.12.059

52. Uhl M, Mattke M, Welzel T, Roeder F, Oelmann J, Habl G, et al. Highly Effective Treatment of Skull Base Chordoma With Carbon Ion Irradiation Using a Raster Scan Technique in 155 Patients: First Long-Term Results. Cancer (2014) 120(21):3410-7. doi: 10.1002/cncr.28877

53. Mizoe JE, Hasegawa A, Takagi R, Bessho H, Onda T, Tsujii H. Carbon Ion Radiotherapy for Skull Base Chordoma. Skull Base (2009) 19(3):219-24. doi: 10.1055/s-0028-1114295

54. Mima M, Demizu Y, Jin D, Hashimoto N, Takagi M, Terashima K, et al. Particle Therapy Using Carbon Ions or Protons as a Definitive Therapy for Patients With Primary Sacral Chordoma. Br J Radiol (2014) 87 (1033):20130512. doi: 10.1259/bjr.20130512

55. Uhl M, Welzel T, Jensen A, Ellerbrock M, Haberer T, Jäkel O, et al. Carbon Ion Beam Treatment in Patients With Primary and Recurrent Sacrococcygeal Chordoma. Strahlenther Onkol (2015) 191(7):597-603. doi: 10.1007/s00066-015-0825-3

56. Mattke M, Vogt K, Bougatf N, Welzel T, Oelmann-Avendano J, Hauswald $\mathrm{H}$, et al. High Control Rates of Proton- and Carbon-Ion-Beam Treatment With Intensity-Modulated Active Raster Scanning in 101 Patients With Skull Base Chondrosarcoma at the Heidelberg Ion Beam Therapy Center. Cancer (2018) 124(9):2036-44. doi: 10.1002/cncr.31298

57. Yang J, Hu W, Guan X, Hu J, Gao J, Qiu X, et al. Particle Beam Radiation Therapy for Skull Base Sarcomas. Front Oncol (2020) 10:1368. doi: 10.3389/ fonc. 2020.01368

58. El Shafie RA, Czech M, Kessel KA, Habermehl D, Weber D, Rieken S, et al. Evaluation of Particle Radiotherapy for the Re-Irradiation of Recurrent Intracranial Meningioma. Radiat Oncol (2018) 13(1):86. doi: 10.1186/ s13014-018-1026-x

59. Ishikawa H, Tsuji H, Kamada T, Hirasawa N, Yanagi T, Mizoe JE, et al. Adverse Effects of Androgen Deprivation Therapy on Persistent Genitourinary Complications After Carbon Ion Radiotherapy for Prostate Cancer. Int J Radiat Oncol Biol Phys (2008) 72(1):78-84. doi: 10.1016/ j.ijrobp.2007.12.044

60. Nomiya T, Tsuji H, Maruyama K, Toyama S, Suzuki H, Akakura K, et al. Phase I/II Trial of Definitive Carbon Ion Radiotherapy for Prostate Cancer: Evaluation of Shortening of Treatment Period to 3 Weeks. Br J Cancer (2014) 110(10):2389-95. doi: 10.1038/bjc.2014.191

61. Okada T, Tsuji H, Kamada T, Akakura K, Suzuki H, Shimazaki J, et al. Carbon Ion Radiotherapy in Advanced Hypofractionated Regimens for Prostate Cancer: From 20 to 16 Fractions. Int J Radiat Oncol Biol Phys (2012) 84(4):968-72. doi: 10.1016/j.ijrobp.2012.01.072

62. Nomiya T, Tsuji H, Kawamura H, Ohno T, Toyama S, Shioyama Y, et al. A Multi-Institutional Analysis of Prospective Studies of Carbon Ion Radiotherapy for Prostate Cancer: A Report From the Japan Carbon Ion Radiation Oncology Study Group (J-CROS). Radiother Oncol (2016) 121 (2):288-93. doi: 10.1016/j.radonc.2016.10.009

63. Wakatsuki M, Kato S, Ohno T, Karasawa K, Ando K, Kiyohara H, et al. Dose-Escalation Study of Carbon Ion Radiotherapy for Locally Advanced Squamous Cell Carcinoma of the Uterine Cervix (9902). Gynecol Oncol (2014) 132(1):87-92. doi: 10.1016/j.ygyno.2013.10.021

64. Imada H, Kato H, Yasuda S, Yamada S, Yanagi T, Kishimoto R, et al. Comparison of Efficacy and Toxicity of Short-Course Carbon Ion Radiotherapy for Hepatocellular Carcinoma Depending on Their Proximity to the Porta Hepatis. Radiother Oncol (2010) 96(2):231-5. doi: 10.1016/j.radonc.2010.05.019

65. Shinoto M, Yamada S, Terashima K, Yasuda S, Shioyama Y, Honda H, et al. Carbon Ion Radiation Therapy With Concurrent Gemcitabine for Patients
With Locally Advanced Pancreatic Cancer. Int J Radiat Oncol Biol Phys (2016) 95(1):498-504. doi: 10.1016/j.ijrobp.2015.12.362

66. Kato H, Tsujii H, Miyamoto T, Mizoe JE, Kamada T, Tsuji H, et al. Results of the First Prospective Study of Carbon Ion Radiotherapy for Hepatocellular Carcinoma With Liver Cirrhosis. Int J Radiat Oncol Biol Phys (2004) 59 (5):1468-76. doi: 10.1016/j.ijrobp.2004.01.032

67. Kasuya G, Kato H, Yasuda S, Tsuji H, Yamada S, Haruyama Y, et al. Progressive Hypofractionated Carbon-Ion Radiotherapy for Hepatocellular Carcinoma: Combined Analyses of 2 Prospective Trials. Cancer (2017) 123 (20):3955-65. doi: 10.1002/cncr.30816

68. Komatsu S, Fukumoto T, Demizu Y, Miyawaki D, Terashima K, Sasaki R, et al. Clinical Results and Risk Factors of Proton and Carbon Ion Therapy for Hepatocellular Carcinoma. Cancer (2011) 117(21):4890-904. doi: 10.1002/ cncr.26134

69. Shiba S, Abe T, Shibuya K, Katoh H, Koyama Y, Shimada H, et al. Carbon Ion Radiotherapy for 80 Years or Older Patients With Hepatocellular Carcinoma. BMC Cancer (2017) 17(1):721. doi: 10.1186/s12885-017-3724-4

70. Shinoto M, Yamada S, Yasuda S, Imada H, Shioyama Y, Honda H, et al. Phase 1 Trial of Preoperative, Short-Course Carbon-Ion Radiotherapy for Patients With Resectable Pancreatic Cancer. Cancer (2013) 119(1):45-51. doi: $10.1002 /$ cncr.27723

71. Shinoto M, Terashima K, Suefuji H, Matsunobu A, Toyama S, Fukunishi K, et al. A Single Institutional Experience of Combined Carbon-Ion Radiotherapy and Chemotherapy for Unresectable Locally Advanced Pancreatic Cancer. Radiother Oncol (2018) 129(2):333-9. doi: 10.1016/ j.radonc.2018.08.026

72. Kawashiro S, Yamada S, Okamoto M, Ohno T, Nakano T, Shinoto M, et al. Multi-Institutional Study of Carbon-Ion Radiotherapy for Locally Advanced Pancreatic Cancer: Japan Carbon-Ion Radiation Oncology Study Group (JCROS) Study 1403 Pancreas. Int J Radiat Oncol Biol Phys (2018) 101 (5):1212-21. doi: 10.1016/j.ijrobp.2018.04.057

73. Jensen AD, Poulakis M, Nikoghosyan AV, Chaudhri N, Uhl M, Münter MW, et al. Re-Irradiation of Adenoid Cystic Carcinoma: Analysis and Evaluation of Outcome in 52 Consecutive Patients Treated With RasterScanned Carbon Ion Therapy. Radiother Oncol (2015) 114(2):182-8. doi: 10.1016/j.radonc.2015.01.002

74. Yamada S, Kamada T, Ebner DK, Shinoto M, Terashima K, Isozaki Y, et al. Carbon-Ion Radiation Therapy for Pelvic Recurrence of Rectal Cancer. Int $J$ Radiat Oncol Biol Phys (2016) 96(1):93-101. doi: 10.1016/j.jirobp.2016.04.022

75. Zhang W, Hu W, Hu J, Gao J, Yang J, Kong L, et al. Carbon Ion Radiation Therapy for Sinonasal Malignancies: Promising Results From 2282 Cases From the Real World. Cancer Sci (2020) 111(12):4465-79. doi: 10.1111/ cas. 14650

76. Karasawa K, Omatsu T, Arakawa A, Yamamoto N, Ishikawa T, Saito M, et al. A Phase I Clinical Trial of Carbon Ion Radiotherapy for Stage I Breast Cancer: Clinical and Pathological Evaluation. J Radiat Res (2019) 60(3):3427. doi: $10.1093 / \mathrm{jrr} / \mathrm{rry} 113$

77. Harada M, Karasawa K, Yasuda S, Kamada T, Nemoto K. One Shot of Carbon-Ion Radiotherapy Cured a 6-Cm Chemo-Resistant Metastatic Liver Tumor: A Case of Breast Cancer. Jpn J Radiol (2015) 33(9):598-602. doi: 10.1007/s11604-015-0462-x

78. Haume K, Rosa S, Grellet S, Śmiałek MA, Butterworth KT, Solov'yov AV, et al. Gold Nanoparticles for Cancer Radiotherapy: A Review. Cancer Nanotechnol (2016) 7(1):8. doi: 10.1186/s12645-016-0021-x

79. Dai Y, Wei Q, Schwager C, Hanne J, Zhou C, Herfarth K, et al. Oncogene Addiction and Radiation Oncology: Effect of Radiotherapy With Photons and Carbon Ions in ALK-EML4 Translocated NSCLC. Radiat Oncol (2018) 13(1):1. doi: 10.1186/s13014-017-0947-0

80. Dai Y, Wei Q, Schwager C, Moustafa M, Zhou C, Lipson KE, et al Synergistic Effects of Crizotinib and Radiotherapy in Experimental EML4 ALK Fusion Positive Lung Cancer. Radiother Oncol (2015) 114(2):173-81. doi: 10.1016/j.radonc.2014.12.009

81. Kubo N, Noda SE, Takahashi A, Yoshida Y, Oike T, Murata K, et al Radiosensitizing Effect of Carboplatin and Paclitaxel to Carbon-Ion Beam Irradiation in the non-Small-Cell Lung Cancer Cell Line H460. J Radiat Res (2015) 56(2):229-38. doi: 10.1093/jrr/rru085

82. Liu Y, Liu X, Jin X, He P, Zheng X, Dai Z, et al. The Dependence of Radiation Enhancement Effect on the Concentration of Gold Nanoparticles Exposed to 
Low- and High-LET Radiations. Phys Med (2015) 31(3):210-8. doi: 10.1016/ j.ejmp.2015.01.006

83. Wozny AS, Aloy MT, Alphonse G, Magné N, Janier M, Tillement O, et al. Gadolinium-Based Nanoparticles as Sensitizing Agents to Carbon Ions in Head and Neck Tumor Cells. Nanomedicine (2017) 13(8):2655-60. doi: 10.1016/j.nano.2017.07.015

84. Shrestha S, Cooper LN, Andreev OA, Reshetnyak YK, Antosh MP. Gold Nanoparticles for Radiation Enhancement In Vivo. Jacobs J Radiat Oncol (2016) 3(1):026.

85. Linam J, Yang LX. Recent Developments in Radiosensitization. Anticancer Res (2015) 35(5):2479-85.

86. Nath K, Guo L, Nancolas B, Nelson DS, Shestov AA, Lee SC, et al. Mechanism of Antineoplastic Activity of Lonidamine. Biochim Biophys Acta (2016) 1866(2):151-62. doi: 10.1016/j.bbcan.2016.08.001

87. Li YC, Fung KP, Kwok TT, Lee CY, Suen YK, Kong SK. Mitochondrial Targeting Drug Lonidamine Triggered Apoptosis in Doxorubicin-Resistant HepG2 Cells. Life Sci (2002) 71(23):2729-40. doi: 10.1016/S0024-3205(02) 02103-3

88. Jin X, Zhou J, Zhang Z, Lv H. Doxorubicin Combined With Betulinic Acid or Lonidamine in RGD Ligand-Targeted pH-Sensitive Micellar System for Ovarian Cancer Treatment. Int J Pharm (2019) 571:118751. doi: 10.1016/ j.ijpharm.2019.118751

89. Liu Y, Zhang X, Zhou M, Nan X, Chen X, Zhang X. MitochondrialTargeting Lonidamine-Doxorubicin Nanoparticles for Synergistic Chemotherapy to Conquer Drug Resistance. ACS Appl Mater Interf (2017) 9(50):43498-507. doi: 10.1021/acsami.7b14577

90. Peng Y, Lu J, Li R, Zhao Y, Hai L, Guo L, et al. Glucose and Triphenylphosphonium Co-Modified Redox-Sensitive Liposomes to Synergistically Treat Glioma With Doxorubicin and Lonidamine. ACS Appl Mat Interf (2021) 13(23):26682-93. doi: 10.1021/acsami.1c02404

91. Raina K, Agarwal R. Combinatorial Strategies for Cancer Eradication by Silibinin and Cytotoxic Agents: Efficacy and Mechanisms. Acta Pharmacol $\operatorname{Sin}(2007)$ 28(9):1466-75. doi: 10.1111/j.1745-7254.2007.00691.x

92. Hoos A. Development of Immuno-Oncology Drugs - From CTLA4 to PD1 to the Next Generations. Nat Rev Drug Discov (2016) 15(4):235-47. doi: $10.1038 / \mathrm{nrd} .2015 .35$

93. Casaluce F, Sgambato A, Maione P, Rossi A, Ferrara C, Napolitano A, et al. ALK Inhibitors: A New Targeted Therapy in the Treatment of Advanced NSCLC. Target Oncol (2013) 8(1):55-67. doi: 10.1007/s11523-012-0250-9

94. Liu Y, Zhang P, Li F, Jin X, Li J, Chen W, et al. Metal-Based NanoEnhancers for Future Radiotherapy: Radiosensitizing and Synergistic Effects on Tumor Cells. Theranostics (2018) 8(7):1824-49. doi: 10.7150/thno.22172

95. Kim SR, Kim EH. Feasibility Study on the Use of Gold Nanoparticles in Fractionated Kilovoltage X-Ray Treatment of Melanoma. Int J Radiat Biol (2018) 94(1):8-16. doi: 10.1080/09553002.2018.1393579

96. Hainfeld JF, Slatkin DN, Smilowitz HM. The Use of Gold Nanoparticles to Enhance Radiotherapy in Mice. Phys Med Biol (2004) 49(18):N309-15. doi: $10.1088 / 0031-9155 / 49 / 18 / \mathrm{N} 03$

97. Zhang XD, Luo Z, Chen J, Shen X, Song S, Sun Y, et al. Ultrasmall Au(10-12) (SG)(10-12) Nanomolecules for High Tumor Specificity and Cancer Radiotherapy. Adv Mater (2014) 26(26):4565-8. doi: 10.1002/adma.201400866

98. Wang Z, Shao D, Chang Z, Lu M, Wang Y, Yue J, et al. Janus Gold Nanoplatform for Synergetic Chemoradiotherapy and Computed Tomography Imaging of Hepatocellular Carcinoma. ACS Nano (2017) 11 (12):12732-41. doi: 10.1021/acsnano.7b07486

99. Chang Y, He L, Li Z, Zeng L, Song Z, Li P, et al. Designing Core-Shell Gold and Selenium Nanocomposites for Cancer Radiochemotherapy. ACS Nano (2017) 11(5):4848-58. doi: 10.1021/acsnano.7b01346

100. Huang W, He L, Ouyang J, Chen Q, Liu C, Tao W, et al. Triangle-Shaped Tellurium Nanostars Potentiate Radiotherapy by Boosting Checkpoint Blockade Immunotherapy. Matter (2020) 3(5):1725-53. doi: 10.1016/ j.matt.2020.08.027
101. Duo Y, Huang Y, Liang W, Yuan R, Li Y, Chen T, et al. Ultraeffective Cancer Therapy With an Antimonene-Based X-Ray Radiosensitizer. Adv Funct Mat (2020) 30(4):1906010. doi: 10.1002/adfm.201906010

102. Kotb S, Detappe A, Lux F, Appaix F, Barbier EL, Tran VL, et al. GadoliniumBased Nanoparticles and Radiation Therapy for Multiple Brain Melanoma Metastases: Proof of Concept Before Phase I Trial. Theranostics (2016) 6 (3):418-27. doi: 10.7150/thno.14018

103. Ma XH, Gong A, Xiang LC, Chen TX, Gao YX, Liang XJ, et al. Biocompatible Composite Nanoparticles With Large Longitudinal Relaxivity for Targeted Imaging and Early Diagnosis of Cancer. J Mater Chem B (2013) 1(27):341928. doi: $10.1039 / \mathrm{c} 3 \mathrm{tb} 20648 \mathrm{c}$

104. Amirrashedi M, Riyahialam N, Mostaar A, Haghgoo S, Jaberi R. Dose Enhancement in Radiotherapy by Novel Application of Gadolinium Based MRI Contrast Agent Nanomagnetic Particles in Gel Dosimetry. Int J Hydrogen Energy (2015) 51:816-22. doi: 10.1007/978-3-319-19387-8_200

105. Song G, Cheng L, Chao Y, Yang K, Liu Z. Emerging Nanotechnology and Advanced Materials for Cancer Radiation Therapy. Adv Mater (2017) 29 (32):1700996. doi: 10.1002/adma.201700996

106. Laprise-Pelletier M, Simão T, Fortin MA. Gold Nanoparticles in Radiotherapy and Recent Progress in Nanobrachy Therapy. Adv Healthcare Mater (2018) 7(16):e1701460. doi: 10.1002/adhm.201701460

107. Zhao X, Qi T, Kong C, Hao M, Wang Y, Li J, et al. Photothermal Exposure of Polydopamine-Coated Branched Au-Ag Nanoparticles Induces Cell Cycle Arrest, Apoptosis, and Autophagy in Human Bladder Cancer Cells. Int J Nanomed (2018) 13:6413-28. doi: 10.2147/IJN.S174349

108. Youkhana EQ, Feltis B, Blencowe A, Geso M. Titanium Dioxide Nanoparticles as Radiosensitisers: An In Vitro and Phantom-Based Study. Int J Med Sci (2017) 14(6):602-14. doi: 10.7150/ijms.19058

109. Du F, Lou J, Jiang R, Fang Z, Zhao X, Niu Y, et al. Hyaluronic AcidFunctionalized Bismuth Oxide Nanoparticles for Computed Tomography Imaging-Guided Radiotherapy of Tumor. Int J Nanomed (2017) 12:5973-92. doi: $10.2147 /$ IJN.S130455

110. Kuncic Z, Lacombe S. Nanoparticle Radio-Enhancement: Principles, Progress and Application to Cancer Treatment. Phys Med Biol (2018) 63 (2):02tr01. doi: 10.1088/1361-6560/aa99ce

111. Kaur H, Pujari G, Semwal MK, Sarma A, Avasthi DK. In Vitro Studies on Radiosensitization Effect of Glucose Capped Gold Nanoparticles in Photon and Ion Irradiation of HeLa Cells. Nucl Instrum Meth B (2013) 301:7-11. doi: 10.1016/j.nimb.2013.02.015

112. Porcel E, Liehn S, Remita H, Usami N, Kobayashi K, Furusawa Y, et al. Platinum Nanoparticles: A Promising Material for Future Cancer Therapy? Nanotechnology (2010) 21(8):85103. doi: 10.1088/0957-4484/21/8/085103

113. Porcel E, Tillement O, Lux F, Mowat P, Usami N, Kobayashi K, et al. GadoliniumBased Nanoparticles to Improve the Hadrontherapy Performances. Nanomedicine (2014) 10(8):1601-8. doi: 10.1016/j.nano.2014.05.005

114. Li F, Li Z, Jin X, Liu Y, Li P, Shen Z, et al. Radiosensitizing Effect of Gadolinium Oxide Nanocrystals in NSCLC Cells Under Carbon Ion Irradiation. Nanoscale Res Lett (2019) 14(1):328. doi: 10.1186/s11671-019-3152-2

115. Helm A, Ebner DK, Tinganelli W, Simoniello P, Bisio A, Marchesano V, et al. Combining Heavy-Ion Therapy With Immunotherapy: An Update on Recent Developments. Int J Part Ther (2018) 5(1):84-93. doi: 10.14338/IJPT-18-00024.1

Conflict of Interest: The authors declare that the research was conducted in the absence of any commercial or financial relationships that could be construed as a potential conflict of interest.

Copyright $\odot 2021$ Wang, Chen, Li, Han, Gao, Liu and Tang. This is an open-access article distributed under the terms of the Creative Commons Attribution License (CC BY). The use, distribution or reproduction in other forums is permitted, provided the original author(s) and the copyright owner(s) are credited and that the original publication in this journal is cited, in accordance with accepted academic practice. No use, distribution or reproduction is permitted which does not comply with these terms. 